\title{
Does reporting transparency affect industry coordination? Evidence from the duration of international cartels
}

\author{
Igor Goncharov* \\ Lancaster University Management School \\ Caspar David Peter \\ Rotterdam School of Management, Erasmus University
}

This version: April 2018

\begin{abstract}
Firms coordinate their actions with industry peers, thereby affecting product market competition. Using the cartel setting, we investigate how financial reporting transparency affects industry coordination. Economic theory predicts that transparency might either prolong cartel duration through increased contracting efficiency or destabilize cartels due to earlier detection of deviating members. We test these predictions on firms indicted by the European Commission for anticompetitive behavior between 1980 and 2010. Using reporting under internationally recognized accounting standards (IFRS or U.S. GAAP) as our measure of reporting transparency, we find that following a transparent accounting framework decreases cartel duration. We show that this finding is partly explained by transparent segment disclosure, which provides a means for the verification of agreed-upon sales for a given product or region. Consistent with the view that transparent reporting leads to earlier detection of deviating members, we further show that transparency lowers cartel duration when the likelihood of cheating is high.
\end{abstract}

Key Terms: Reporting transparency, IFRS, cartels, competition

We appreciate helpful comments from Dan Collins, Begoña Giner, Andreas Hoepner, Allan Hodgson, Katharina Hombach, Martin Jacob, Laurence van Lent, Patrick McColgan, Maximilian Müller, Zacharias Sautner, Hans Schultz, Thorsten Sellhorn, Harm Schütt, Jörg Werner, T.J. Wong (the Editor), two anonymous reviewers and workshop participants at the Frankfurt School of Finance, Free University of Berlin, German Monopolies Commission (Monopolkommission), LSE, University of Gießen, WHU, the EAA annual congress, the European Economic Association meeting, and the Workshop on Empirical Research in Financial Accounting. We thank John Connor for providing us with an excerpt of the private international cartel spreadsheet, and Karin Engelmann for excellent research assistance.

\footnotetext{
* Contact author: Igor Goncharov, Lancaster University Management School, Lancaster University, Bailrigg, Lancaster, Lancashire LA1 4YX, U.K.; Tel. +44 (0)1524 593642; Fax: +44 (0)1524 847321; e-mail: i.goncharov@lancaster.ac.uk.
} 


\title{
Does reporting transparency affect industry coordination? Evidence from the duration of international cartels
}

\begin{abstract}
Firms coordinate their actions with industry peers, thereby affecting product market competition. Using the cartel setting, we investigate how financial reporting transparency affects industry coordination. Economic theory predicts that transparency might either prolong cartel duration through increased contracting efficiency or destabilize cartels due to earlier detection of deviating members. We test these predictions on firms indicted by the European Commission for anticompetitive behavior between 1980 and 2010. Using reporting under internationally recognized accounting standards (IFRS or U.S. GAAP) as our measure of reporting transparency, we find that following a transparent accounting framework decreases cartel duration. We show that this finding is partly explained by transparent segment disclosure, which provides a means for the verification of agreed-upon sales for a given product or region. Consistent with the view that transparent reporting leads to earlier detection of deviating members, we further show that transparency lowers cartel duration when the likelihood of cheating is high.
\end{abstract}

Key Terms: Reporting transparency, IFRS, cartels, competition 


\section{Does reporting transparency affect industry coordination? Evidence from the duration of international cartels}

\section{INTRODUCTION}

In product markets, firms have incentives to coordinate their actions, raise prices above the competitive level, and share collective profits, because industry coordination decreases the strategic uncertainties originating from competitive pressure (Stigler 1964). However, firms face a trade-off: Coordination among firms is sustained only as long as the collective returns from cooperation outweigh the short-term private returns from defection (Dick 1996). While economic theory predicts that financial reporting transparency affects this trade-off, no prior evidence exists as to whether transparency either facilitates industry coordination through increased contracting efficiency or impedes industry coordination due to the earlier detection of deviating members. We exploit an international sample of firms that have been indicted by the European Commission (EC) for forming illegal cartels. The use of cartels allows us to observe the nature and duration of industry coordination, and to examine how reporting transparency affects industry coordination and competition.

To derive our predictions, we combine theories explaining the sustainability of cartels with the literature on the role of accounting information in contracting (Ball et al. 2008; Stigler 1964). Contracting theory suggests that transparency is a mechanism for reducing contracting costs by making readily available the information necessary for monitoring, enforcing, and verifying a cartel agreement (e.g., Williamson 1973). Leslie (2004) concludes that contracting costs hinder firms in oligopolistic markets from forming cartels. Because disaggregated accounting information is used for allocating and monitoring production quotas within the cartel, reporting transparency may decrease contracting costs by allowing for more efficient contracting between agents (Jensen and Meckling 1976; Lambert 2001; Hölmstrom 1979; Watts and Zimmerman 1986). Anecdotally, cartel members use publicly available audited financial information both to verify self-reported sales and to enforce the cartel agreement (Harrington Jr. 2006; Harrington Jr. and Skrzypacz 2011). Similarly, cartel regulators argue that (mandatory) public disclosures convey coordination benefits and allow cartels to avoid prosecution 
(OECD 2010). Thus, by decreasing contracting costs, reporting transparency may increase cartel duration.

Unlike debt and compensation contracts, implicit cartel contracts lack legal standing; instead, they depend upon self-enforcement by the cartel members. Game theory suggests that industry coordination is an example of prisoner's dilemma (Pepall et al. 2005): Given that the opportunity costs of cooperation are high for individual firms, cartel members are tempted to employ the short-term strategy of cheating (Roberts 1985). Transparent reporting provides cartel members the means for verifying self-reported numbers and thus leads to earlier detection of cheating. Upon the discovery of cheating, the other cartel members can either invest in deterrence mechanisms or punish the cheating members (Levenstein 1997). The first option raises deterrence costs, which reduce the collective returns from collusion (Abreu et al. 1991) and can cause a cartel to break up (Stigler 1964). The second option leads to a price war, which destabilizes cartels (Levenstein 1997). Thus, when cartel members cheat, financial reporting transparency may decrease cartel duration by making collusion costly to sustain.

We hypothesize financial reporting transparency can decrease cartel duration when cartel members cheat, because transparency enhances the cartel members' ability to detect deviations from the cartel agreement. When cartel members do not defect or when cartels have effective mechanisms for dealing with cheating, financial reporting transparency may increase cartel duration and help cartel members sustain the cartel agreement through the provision of credible and verifiable sources of public information. We test these predictions using the requirement to report under internationally recognized accounting standards as our measure of reporting transparency. We designate U.S. GAAP, IFRS, and IFRS' predecessor IAS, as transparent accounting standards, arguing that they provide three benefits for enforcing cartel agreements (hereafter, we use IFRS to mean both IAS and IFRS).

First, the disclosure literature shows that these accounting standards demand higher levels of disclosure than local GAAP (Leuz and Verrecchia 2000; Daske and Gebhardt 2006). Specifically, they mandate disclosure of disaggregated segment information (e.g., SFAS 131, IAS 14), while local GAAP frequently does not. Because of a high demand for the verification of firm sales in the cartel setting 
(Doblin 1943), cartel members can use segment reporting to allocate market shares and to compare agreed-upon market shares to reported sales for a given product or region. While transparent segment reporting can facilitate contracting, it also reveals any deviations from the cartel agreement. Second, transparent accounting standards facilitate the comparison of financial information across markets in global cartels (Brochet et al. 2013). Third, transparent accounting standards mitigate earnings management, thereby reducing the possibilities of hiding cheating and increasing the contracting relevance of accounting information (Barth et al. 2008; González et al. 2015).

We test our predictions using an international sample of price-fixing cartels convicted of violating Article 101 of the Treaty on the Functioning of the European Union (EU). Using the Cox proportional hazard model, we find that reporting transparency is associated with a lower cartel duration. This result is consistent with the notion that transparent reporting on average leads to earlier detection of cheating, thereby increasing the costs of deterrence and the likelihood of a price war. In supplemental tests, we show that this finding is explained (in part) by transparent segment disclosure, which provides a means for the verification of agreed-upon sales for a given product or region. Specifically, we find that firms report a greater number of segments when they follow U.S. GAAP and IFRS than when they follow local GAAP. We also find that the increase in the number of reported segments is associated with the lower cartel duration. However, when cartel firms constantly reclassify information across business segments as González et al. (2015) found, the resulting opacity of segment information extends the cartel lifespan.

To further support the role of reporting transparency in cheating discovery, we exploit crosssectional variation in the likelihood of cheating and the cartel response to cheating. The economic literature predicts that cartel members are more likely to defect when a cartel lacks effective means of enforcing the cartel agreement and when the costs that other cartel members impose on the cheating firm are low (Levenstein and Suslow 2006). Furthermore, cheating is more likely when cartel members have heterogeneous cost structures, because more profitable firms can afford a larger price cut and can gain a larger market share by defecting (Tirole 1988). 
Using empirical proxies for the likelihood of cheating, we find that transparent reporting is associated with decreases in cartel duration when cartel members are likely to cheat, and that transparent reporters experience a decrease in cartel duration when the likelihood of cheating increases. While these results strongly suggest that transparent reporting reduces cartel duration because it reveals cheating, we do not find any significant results for the contracting benefits of transparent reporting or an increase in cartel duration for transparent reporters when the likelihood of cheating is relatively low. This result supports the view that transparent reporting predominantly affects cartel duration by allowing the cartel members to more effectively monitor the non-enforceable cartel agreement and to detect cheating. However, our failure to find any contracting benefits of transparent reporting may be also explained by the overall frequency of cheating, which is even greater in our sample of failed cartels, because cheating is the dominant short-term strategy and the cartels that broke up are more likely to have cheated. ${ }^{1}$ If cheating is widespread, our empirical tests may fail to provide a powerful test of whether transparent reporting has some contracting benefits in the cartel setting. ${ }^{2}$

We employ a battery of sensitivity checks to rule out alternative explanations for our results. To alleviate endogeneity concerns stemming from cartel members' voluntary IFRS adoption, we endogenize the cartel members' voluntary choice of using IFRS. We also exploit heterogeneity in the transparency of (mandatory) local GAAP, the requirement that listed U.S. firms use U.S. GAAP, and the requirement to report business segments. Furthermore, because we can only observe indicted cartels, our sampling procedure is not random, and our results may be affected by the regulator's involvement. To control for this selection bias, we use the two-stage Heckman estimation method, while also showing that our results are robust to using the sub-sample of cartels that dissolved before the start of the investigation by the regulator. While our tests use fixed effects and explicit controls for country, industry, firm, and timespecific factors, standard concerns with analyses involving a heterogeneous sample of firms imply that our results should be regarded as suggestive, not conclusive.

\footnotetext{
${ }^{1}$ In-depth case studies of cartels find that cheating plays some role in the demise of up to 60 percent of examined cartel cases (Levenstein and Suslow 2006; Eckbo 1976; Griffin 2000).

${ }^{2}$ While we can identify cartels with characteristics that make cheating increasingly unlikely, "switching off” the effect of cheating requires fine sample partitions that substantially reduce the power of our tests.
} 
As our paper is the first to provide evidence on how reporting transparency affects industry coordination and product market competition, our contribution is threefold. First, we add to prior work on the relation between firms' competitive environment and the level of reporting transparency (Verrecchia 2001; Datta et al. 2013). These studies examine the effect of competition on the quantity and quality of disclosure (Verrecchia 2001) or earnings management (Datta et al. 2013). Consistent with theoretical predictions in Bagnoli and Watts (2010), we show that the reverse effect is possible and that reporting transparency can affect industry coordination and competition through enhanced monitoring ability.

Second, our study adds to the literature on the verification role of audited financial statements (Ball et al. 2012; Lisowsky et al. 2017; Minnis 2011; Minnis and Sutherland 2017). We contribute to this literature by showing that the verification role of audited financial reporting extends to non-enforceable contracts. Third, by explicitly considering the effect of transparency on cartel duration, we contribute to the economic literature that analyzes cartel duration and its determinants (Suslow 2005; Levenstein and Suslow 2011). From a policy standpoint, transparent reporting-because it fosters competition by reducing cartel sustainability—may have positive consumer welfare implications. Therefore, our results contribute to the debate on whether transparent reporting can influence efficient resource allocation in an economy (Bushman et al. 2011).

The paper proceeds as follows. Section II reviews the cartel setting, section III develops our hypotheses, and section IV reports on the sample selection. Section V presents the main empirical results, which are followed by robustness tests in section VI. Section VII concludes.

\section{THE CARTEL SETTING}

In competitive product markets, firms coordinate their actions because firms determine industry prices and outputs conditional on the actions of their rivals. Collusion is widespread because it obviates the uncertainties of independent actions and reduces the complexity of interdependencies between firms (Asch and Seneca 1976). Collusion varies in degree, from the sole expectation that a rival will not act independently in its weakest form (joint ventures or trade organizations), to a firm's sticking to an 
agreement only as long as its rivals do (cartels) (Lipczynski et al. 2005). Successful collusion is sustainable as long as the firm's share of long-term collusion profits is higher than the short-term gain of deviation from collusion (Dick 1996).

A cartel is an implicit agreement between firms in the same industry to fix prices or industry outputs, to allocate territories, or to divide profits (OECD 2007). The key measure of cartel success is duration. A number of studies show that average cartel duration varies from 6 to 11 years, depending on sample composition (Zimmerman and Connor 2005; Levenstein and Suslow 2011; De 2010). Cartel members seek to act collectively, as if they were a single monopolist, thereby maximizing the collective profit. By doing so, cartels violate competition policy and severely reduce consumer welfare through price-fixing activities that increase the price of goods far beyond the competitive level (Tirole 1988). Recent evidence shows that the average price overcharges by cartels prosecuted by U.S. and EU cartel authorities were 48.4 and 32.2 percent, respectively (Connor 2014). The total fines that the EC imposed on cartels in the period 1990-2015 amounted to €21 billion. However, this amount is only a small fraction of the estimated \$1.5 trillion in damages caused by international cartels over the same period (Connor 2014).

The salient feature of cartel agreements - that they are not enforceable in court and that therefore only cartel members can enforce them—leads to a strong demand for monitoring activities. However, given each cartel member's temptation to deceive the other members by undercutting the agreed-upon collusive price, enforcement is difficult (Suslow 2005; Stigler 1964). Therefore, early cartel studies view cartel members as police officers that punish any deviators, concluding that a price war must erupt whenever a co-conspirator deviates (e.g., Green and Porter 1984). Recent studies attempt to explain the existence of different stabilizing mechanisms that cartels employ, such as further information gathering, involving third-party monitors, and taking away firms' ability to quickly implement operating changes (Harrington Jr. and Skrzypacz 2007; Sannikov and Skrzypacz 2007). However, Abreu et al. (1986) show that cheating and the mechanisms cartel members implement to circumvent it raise the cost of deterrence and ultimately decrease the benefits of collusion. 
As cartel members cannot directly observe one another's production levels, they need to gather further information to verify whether their co-conspirators are sticking to the agreed-upon quantities or prices (Green and Porter 1984). Because prices cannot be observed in wholesale markets, they cannot be used for monitoring cartel agreements. ${ }^{3}$ Importantly, prices depend on total market supply and thus tell us little about the actions of individual cartel members (Sannikov and Skrzypacz 2007). To monitor the cartel agreement effectively, cartel members need information, summarized in the form of firm sales, on the output and prices set by individual cartel members. Therefore, Harrington Jr. and Skrzypacz (2007, 314) conclude that cartels "go to great lengths to ensure that sales are public information among the cartel members.” Furthermore, Sannikov and Skrzypacz (2007) show that collusion would be impossible if monitoring used only information on total market supply (e.g., prices) rather than on individual decisions such as firm sales. Consequently, the availability of financial information is a necessary condition for cartel formation.

Published financial statements provide a number of advantages in the cartel setting. They report information on total sales as well as product and regional sales, so that cartel members can allocate outputs or territories within the cartel and verify information about individual production and sales decisions. Disaggregate accounting information is used in production-related contract clauses, which help cartels in allocating sales and production according to each cartel members' production efficiency (Hyytinen et al. 2017). The accounting information can also help cartels estimate the potential additional market supply from non-member rivals and allow those cartels to adopt their policies and the allocation method to threats from new entrants (Fink et al. 2017). While much of the literature focuses on the importance of sales data, Athey and Bagwell (2001) show that allocation methods can achieve production efficiency only if cartel members (truthfully) communicate cost information. Because published financial statements provide the data necessary for sustaining and monitoring the cartel agreement, the members of the “Carbonless Paper Cartel” used other cartel members' financial statements to verify the accuracy of internally self-reported sales (Harrington Jr. and Skrzypacz 2011).

\footnotetext{
${ }^{3}$ When firms sell goods to retail and wholesale customers, the wholesalers have an effect on observable retail prices.
} 
Although cartel members meet secretly to coordinate their actions and exchange information, a high degree of mistrust in the self-reported information exists. For example, the "Amino Acid Cartel” hired an accounting firm to monitor the sales reports of individual cartel members (Connor 2001; Harrington Jr. and Skrzypacz 2007). Executives at the meeting of the "Lysine Cartel" complained that prices were too low, suspecting co-conspirator Archer Daniels Midland (ADM) of cheating. ADM, which was indeed cheating, countered the allegations by suggesting that "one can point a lot of fingers" and that "the best thing to do was to find a solution to a problem” (Cabral 2005, 201). Financial statements reduce mistrust because they are audited and presented in a standardized form, making them helpful for international cartels that use comparable figures for their monitoring activities.

Importantly, using publicly available financial statements for monitoring, rather than exchanging private information during meetings, reduces the costs of prosecution. The key issue in prosecuting cartels is finding evidence that a conspiracy has taken place, evidence that can be gathered during unannounced searches of business premises or from cartel members willing to participate in the leniency program (Brenner 2009). Any private information (prepared by one cartel member) found in the possession of another cartel member can be used in court as evidence of conspiracy. ${ }^{4}$ Conversely, cartels that coordinate their actions based on publicly available information can escape prosecution. For example, the German Cartel Office found that price changes at major fuel retail firms showed evidence that the firms had coordinated their fuel prices. Yet the authorities could not prove any wrongdoing because the coordination mechanism apparently relied only on publicly available information (Bundeskartellamt 2011). ${ }^{5}$

While the availability of financial information can enable cartel formation, cartel sustainability depends on whether transparent reporting reduces contracting costs or destabilizes the cartel by revealing

\footnotetext{
${ }^{4}$ The U.S. Department of Justice finds that cartel members routinely give each other "explicit instructions to destroy any evidence of the conspiracy” (Griffin 2000).

${ }^{5}$ The EU General Court concluded “... That if the information is in the public domain as a result of mandatory disclosure requirements (in that case compulsory publication under U.S. law) or if it can be easily deduced from publicly available information, the exchange of this information between competitors cannot be considered an infringement of the EU Treaty competition rules” (OECD 2010, 50).
} 
cheating. Thus the ex post effect of reporting transparency on cartel duration remains an empirical question.

\section{HYPOTHESIS DEVELOPMENT}

The accounting literature examines whether a given level of industry competition affects financial disclosures and reporting transparency (see Healy and Palepu, 2001, and Verrecchia, 2001, for a review). It predicts that a firm's competitors can strategically use its financial disclosure. Because firms fear that increased transparency can erode their market position, they adjust the transparency of reported information. This adjustment depends on the nature of the competition (Beyer et al. 2010). For example, when analyzing voluntary disclosure of industry-wide news, Rogers at al. (2014) find that strategic nondisclosure is more likely in industries with greater negative tail risk, greater equity incentives, and industry associations that foster interpersonal connections. Bertomeu et al. (2015) both predict and find that disclosure of production forecasts is more valuable within a tacit agreement, because a tacit agreement reduces the proprietary costs of disclosure. We examine whether the reverse effect is possible, that is, whether the use of transparent financial statements in collusive agreements affects industry competition.

Coordination among cartel members can sustain itself as long as the expected benefits of long-term collusion exceed the short-term private returns from defection (Dick 1996; Pepall et al. 2005). Thus, cartel members seek reliable information for monitoring and policing the cartel agreement (Telser 1980; Williamson 1974), and invest in information gathering to improve their monitoring of individual firms' activities (Levenstein and Suslow 2006). Transparent reporting can reduce contracting costs, which arise through uncertainty and information asymmetry among its members (Williamson 1973; Stigler 1964). As the credibility of information is a critical determinant of cartel duration (Spar 1994), audited financial statements constitute an incremental monitoring device that can reduce contracting costs by providing transparent, publicly observable, and verifiable information (Ball et al. 2008; Watts and Zimmerman 1986; Harrington Jr. 2006). 
Because accounting information is used for facilitating the cartel agreement, the transparency of this information likely has implications for the sustainability of the cartel agreement. For enforceable product-licensing agreements that rely on disaggregate accounting sales data, Kim-Gina (2018) finds that the quality of sales data determines the scope of auditing and penalties for adverse audit outcomes. We argue that transparent accounting standards (IFRS and U.S. GAAP) can help sustain a cartel by requiring greater disclosure than local GAAP (Daske and Gebhardt 2006). Importantly, transparent accounting standards require business-segment and geographic disclosures, both of which reveal detailed information on sales and market shares for monitoring purposes. Furthermore, transparent accounting standards facilitate the comparison of sales and performance figures across countries (Brochet et al. 2013). For example, by unifying revenue recognition criteria, they assist cartels with allocating production and territories, effectively responding to the threats of new entrants, and monitoring market shares. Moreover, transparent accounting standards lower earnings management (Barth et al. 2013; Barth et al. 2008). Because earnings management is a common practice among cartels (González et al. 2015), transparent reporting can increase the reliability of information for monitoring purposes but also decrease verification costs. Thus, by decreasing contracting costs, transparent accounting standards may increase the sustainability of cartels.

However, transparent accounting standards may decrease cartel duration if cartel firms cheat and reporting transparency helps detect cheating. Unlike debt or compensation contracts, the cartel contract has no legal standing and is formed by industry peers. Non-cooperation and cheating at the expense of one's rivals is a short-term dominant strategy among cartel members because, in the short term, the cheating returns to an individual firm may exceed the collective returns of sustaining collusion (Pepall et al. 2005; Roberts 1985). In other words, a strong temptation exists for cartel members to extract one-time gains by undercutting the agreed-upon cartel price (Suslow 2005). Furthermore, because cartels are illegal and non-enforceable, cartel members lack an effective mechanism for controlling cheating (Orr and MacAvoy 1965). Thus transparent reporting can offer an effective means of discovering cheating through segment reporting of sales, a reduction in earnings management, and the provision of comparable 
figures. Therefore, when cartel members cheat, we expect reporting transparency to yield information about cheating, either by unravelling cheating within a transparent firm or by narrowing the circle of suspect firms by excluding complying firms with transparent reporting.

Once cheating is discovered, cartel members face two immediate choices. First, they may choose to invest in costly mechanisms that deter future cheating (Sannikov and Skrzypacz 2007). For example, despite continuously gathering private information on market shares, the Joint Executive Committee Railroad Cartel did not prevent its members from cheating (Ulen 1980; Porter 1983). The cartel had to implement a number of costly mechanisms to stabilize itself after the cheating was discovered (e.g., it hired "very handsomely paid" arbitrators). In another example, the "Lysine Cartel” described earlier included ADM, which reported transparently under U.S. GAAP, and three other firms that used local GAAP. The firm with transparent reporting was suspected of cheating. This cartel's solution was to implement certain mechanisms for deterring cheating. Thus, the discovery of deviations from the cartel agreement raises the cost of deterrence (Abreu et al. 1991). ${ }^{6}$ The literature predicts that cartels will dissolve if those costs become too high (e.g., Stigler 1964; Dick 1996).

Second, the non-cheating cartel members can also choose either to cheat, leading to a price war, or to terminate the cartel in anticipation of one. Levenstein (1997) reports that publicly announced violations of collusive agreements frequently lead to price wars that have ended cartels. Harrington and Skrzypacz's (2011) model shows that cartels are stable as long as they truthfully report sales information. For example, after Uralkali obtained information that its partner was selling outside of the partnership, its CEO announced his firm's decision to terminate an informal global-pricing cartel that had existed for eight years and controlled up to 43 percent of the world potash market (Alpert and MacDonald 2013). We posit that financial reporting transparency may lower cartel duration because it increases the likelihood of detecting cheaters through better means of verifying self-reported numbers, leading to either

\footnotetext{
${ }^{6}$ How transparent reporting affects the cheating rates remains unclear. One argument predicts that firms will be less likely to cheat if they anticipate that cheating is more likely to be discovered. However, Abreu et al. (1991) show that more transparent and frequent reporting increases the number of ways in which firms can cheat and provides incentives for them to devise more effective cheating strategies. Our reasoning holds as long as transparent reporting does not fully deter cheating.
} 
an increase in deterrence costs or a costly price war. We formulate our hypothesis in non-directional form as follows:

H1: The transparency of financial reporting information affects cartel duration.

Because we predict that transparent accounting standards increase the likelihood of detecting cheaters, the average outcome predicted by hypothesis 1 depends on the base rate of cheating in the population. While all cartels have a tendency to cheat, some cartels are sustainable over longer periods while others dissolve quickly which suggests that the propensity to cheat and the response to cheating are not uniform across cartels. The economic literature offers several explanations for differences in the extent of cheating and its effect on cartel sustainability. First, cartels implement organizational structures that help them reduce cheating and stabilize the cartel when cheating is revealed (Stigler 1964). Trade associations can stabilize cartels by stipulating cartel practices, by enforcing the cartel agreement, and by facilitating communication to resolve any disputes (Stigler 1964; Harrington Jr. and Skrzypacz 2011). For example, Genesove and Mullin (2001) review the case of the Sugar Institute, a trade association that enforced the cartel agreement and "sought [customers'] adherence to the agreement through blacklisting deviators..., and instilling a culture of adherence to the codes” (p. 393). When cheating by cartel members did occur, the trade association had measures in place to stabilize the cartel by either matching or ignoring any member's deviation.

Levenstein and Suslow (2011) provide empirical support for the role of trade associations in policing the cartel agreement and show that the involvement of a trade association significantly decreases the likelihood of a cartel break-up. If a trade association is effective in eliminating cheating or coordination of the cartel response to cheating, we predict that financial reporting transparency provides contracting benefits and increases cartel duration. However, when a cartel lacks an effective policing mechanism of a trade association, cheating is relatively more likely and financial reporting transparency is expected to reduce cartel duration through earlier discovery of cheating.

Second, economic theory predicts that excess capacity reduces the likelihood of cheating. When firms cheat, they must trade-off immediate benefits of cheating and the loss due to retaliation by other 
cartel members. The imposed retaliation on a cartel member is determined by the total excess capacity available to the cartel members (Osborne and Pitchik 1987). Reviewing recent cartel cases in the U.S., Kolasky (2002) concludes that excess capacity is effective in punishing cheating and enforcing the cartel agreement. Rosenbaum (1989) argues that inventory holdings can act as excess capacity, facilitating retaliation by selling goods available for sale at a discounted price. We predict that financial reporting transparency increases (decreases) cartel duration when the cartel members possess high (low) excess capacity.

Third, Tirole (1988) argues that differences in the cartel members' cost structures provide incentives for cheating. Some firms have lower costs and earn higher profits than others due to operating efficiencies or different cost structures. These firms have the strongest incentive to cheat, because they can afford a larger price cut while remaining profitable and can gain a larger market share by defecting (Tirole 1988; Caudill and Mixon 1994). We expect that the profit heterogeneity within the cartel provides incentives for cheating and that financial reporting transparency will increase (decrease) cartel duration when cartel members have similar (dissimilar) profitability levels. Using cartel organizational structure, excess capacity, and profit heterogeneity to capture differences in the likelihood of cheating, we formally state our predictions as follows:

H1a: Financial reporting transparency decreases cartel duration when firms cheat and more so if cheating is widespread. When cheating is not expected, financial reporting transparency increases cartel duration by reducing contracting costs.

Next, we provide insights into the attributes of transparent accounting standards that affect cartel duration. Information on sales is fundamental to facilitating and monitoring the cartel agreement, because cartels agree on shares of product and geographical markets. Segment reporting enables the validation of self-reported sales numbers through the breakdown of sales for different markets. While transparent accounting standards such as IFRS (IFRS 8, previously IAS 14) and U.S. GAAP (SFAS 131, previously SFAS 14) require firms to disclose sales at the business-segment level, local GAAP rarely mandated such disclosures. The literature on segment reporting shows that segment information helps investors monitor management actions (Berger and Hann 2007; Cho 2015). By establishing a publicly observable 
validation mechanism for self-reported sales figures, segment disclosure provides a finer description of operations and reduces contracting costs.

Alternatively, segment sales data can lead to earlier cheating discovery, which imposes costly deterrence mechanisms or leads to price wars. Gonzáles et al. (2015) provide evidence supporting the importance of segment information for uncovering cheating, by showing that some cartels change segment classifications to disguise their actions. ${ }^{7}$ This line of argument predicts a negative relationship between the requirement of reporting segment information and cartel duration.

H2: Transparent segment reporting affects cartel duration.

\section{SAMPLE SELECTION}

Our sample consists of all listed firms that violated Article 101 of the Treaty on the Functioning of the EU and that the EC convicted between 1980 and 2010 for forming a horizontal or vertical agreement on price fixing, production quotas, or market shares. We focus on the sample of cartels indicted by the EC to keep the enforcement regime constant while still achieving a high degree of variation in the reporting transparency of the sample firms. This variation stems from variation in national accounting laws in the EU before IFRS adoption and the power of the EC to indict all firms that disrupt trade between EU member states, regardless of their country of origin. As the information on cartel cases is disclosed only when the investigation is completed, the dates over which the cartels operated range between 1980 and 2005. To test our hypotheses, we use (1) Reports on Competition Policy (hereafter, Reports) and the EC website for data on the cartels, their structure, and their duration; (2) Worldscope for accounting data of publicly quoted cartel members; and (3) hand-collected data on segments from public firm financial statements.

We conduct our analysis at two levels of data aggregation. First, we use disaggregated data, with each data point identifying a public firm in a given cartel at a given time (i.e., our unit of analysis is the cartel firm year). To construct a broad set of financial statement variables and to better identify the hypothesized relationships, we use information on public firms with available financial data. Moreover,

\footnotetext{
${ }^{7}$ Overall, they do not find that cartel firms report fewer segments than a matched sample of non-cartel firms (see Gonzáles et al., 2015, table 1), suggesting that some demand emanating from the cartel setting may exist for segment reporting.
} 
we treat public firms as the "ringleaders" because they are larger than private firms and thus enjoy larger market share allocations in cartels and have a greater influence on cartel behavior (Levenstein and Suslow 2011). Second, we aggregate information at the cartel level. While changing the unit of analysis to a cartel decreases the number of observations, it allows us to better align our tests with the hypothesized cartel duration. Furthermore, the aggregated analysis enables us to include all cartels convicted by the EC, including those either with or consisting solely of private firms. Although European private and public firms face similar reporting and disclosure requirements, financial accounting databases have sparse coverage of private firms until the late 1990 s. $^{8}$ Consequently, our tests using private firms rely on data from the Reports rather than data from private firm financial statements.

In total, we have information on 98 cartels consisting of public and private firms. These cartels include 131 public firms with accounting data available on Worldscope, corresponding to 186 cartel firm observations, because some firms participated in more than one cartel during our sample period. The total number of observations in our analysis using disaggregated public firm data is 1,072 cartel firm years (corresponding to 60 unique cartels). Our additional tests at the cartel year and cartel level use 391 and 98 data points, respectively. ${ }^{9}$ Table 1 presents the distribution across countries of the sample used in our disaggregated analysis, and the number of firm-years in which cartel members followed transparent accounting standards.

\section{- Insert Table 1 about here -}

Table 2 reports descriptive statistics for the experimental and control variables used in our tests. The average cartel duration is 10.68 years, which is close to the average of 10.84 years reported in De (2010). The mean cartel fine levied by the EC is €63.41 million. The average (median) cartel has 18.11 (13) member firms, and 37 percent of the firm years report under IFRS or U.S. GAAP.

\section{- Insert Table 2 about here -}

\footnotetext{
${ }^{8}$ EU accounting regulation is based on each firm's legal form, not on its listing status (Burgstahler et al. 2006).

${ }^{9}$ If a cartel has three listed and four non-listed members and lasts for 10 years, we use 30 data points in the cartel firmyear analysis, 10 data points in the aggregated analysis at the cartel-year level, and one observation in the cartel-level analysis.
} 


\section{MAIN RESULTS}

\section{Test of Hypothesis 1: Effect of Reporting Transparency on Cartel Duration}

We use cartel duration as our proxy for the success of the collusion. As lifetime data often violates the normality distribution, we investigate the determinants of cartel duration using the survival analysis technique and the Cox proportional hazard model (Cox 1972). This method is commonly applied in duration analysis because it does not assume any underlying distribution (Levenstein and Suslow 2011; Cleves et al. 2008). We tabulate the estimated hazard coefficients, which indicate the probability of exit from a state in the next period, given survival up to that time. Thus a positive coefficient implies a reduction in cartel duration. We base our inferences on standard errors clustered at the cartel-firm level. In our tests using disaggregated public firm data, the hazard function for firm $i$ is given by

$$
\begin{aligned}
h(t)= & h_{0}(t) \exp \left(\beta_{1} F R T_{i t}+\beta_{2} L E N I E N C Y_{i}+\beta_{3} F I N E_{i}+\beta_{4} R E P E A T_{i}\right. \\
& \left.+\beta_{5} \# M E M B E R_{i t}+\beta_{6} \text { SIZE }_{i t}+\beta_{7} G D P \_G R O W T H_{i t}+\text { Fixed Effects }\right)
\end{aligned}
$$

where $h_{0}(t)$ denotes the baseline hazard function and $t$ is the elapsed time since the firm first joined the cartel. Using cartel duration as the dependent variable has a methodological advantage. Because cartels are illegal, we can observe data only for indicted cartels. The use of indicted cartels in our analysis can lead to a selection bias if the characteristics affecting the start of an investigation are correlated with reporting transparency and cartel duration. ${ }^{10} \quad$ Because the selection bias affects every study on competition policy, Harrington Jr. and Chang (2009) develop a model for endogenizing the population of undiscovered and discovered cartels and then identifying how these two populations are related. Their findings suggest that the analysis of indicted cartels is generally not prone to a selection bias when cartel duration is used as the dependent variable (Harrington Jr. and Chang 2009; Harrington Jr. and Wei 2017). Nevertheless our additional tests control for the selection bias due to the involvement of the regulator.

\footnotetext{
${ }^{10}$ The vast majority of the EC cartel investigations are triggered by the use of the leniency program and complaints from affected parties, rather than some form of active market screening or analysis of publicly available information (Parliament 2009): Over 2005-2010, the EC estimates that 73 percent of its cartel investigations were initiated after it received incriminating information from one of the cartel members (in exchange for a fine reduction), 15 percent of its investigations were initiated after it received complaints from consumers or information from the informants, and 4 percent were based on tip-offs from local cartel authorities and other institutions (based mostly on complaints received by those institutions). Only 6 percent of EC cartel cases were initiated as a result of an in-depth market analysis or sector investigation (OECD 2013).
} 
Evidence shows that internationally recognized accounting standards increase transparency by requiring the provision of comparable information and by mandating more informative disclosure, most notably on business segments (Daske et al. 2013; Lang et al. 2012; Byard et al. 2011). We use an indicator variable FRT that equals 1 if the company follows transparent accounting standards (IFRS or U.S. GAAP), based on Worldscope and Daske et al. (2013), in a given year. The first year of IFRS adoption in our sample varies between 1987 and 2005. The coefficient $\beta_{1}$ tests hypothesis 1 and is predicted to be negative if reporting transparency leads to greater cartel sustainability by reducing contracting costs. Alternatively, $\beta_{1}$ will be positive if reporting transparency reveals cheating and destabilizes a cartel.

We use a set of control variables predicted to affect cartel duration. First, changes in the antitrust policy and enforcement affect cartel stability. To control for changes in the EU's antitrust policy, we focus on the application of the leniency program, which guarantees a reduction in the fine associated with an infringement and provides firms with incentives for reporting their own antitrust violations to cartel authorities (Brenner 2009). Prior literature suggests that the implementation and enforcement of laws ensure their effectiveness, rather than their mere existence (Bhattacharya and Daouk 2002). Therefore, we examine the application of leniency policy on cartel duration, and use an indicator variable LENIENCY that equals 1 for listed cartel firms that participated in the leniency program and 0 otherwise as our ex post measure of enforcement effectiveness. ${ }^{11}$ Harrington Jr. and Chang (2009) predict that if the leniency policy is effective, the duration of the detected cartels should increase, because marginally stable cartels will break down or eventually not form in the first place, whereas only stable cartels will survive. Furthermore, we use fines in percentage of total assets (FINE) to control for changes in the enforcement of antitrust policies. Higher fines can be the result of stricter enforcement, which destabilizes cartels, or they can sustain cartels by increasing the costs of breaking them up (Connor 2004).

\footnotetext{
${ }^{11}$ Our results are robust to alternative specifications of this variable. First, the EC introduced the leniency program in 1996, leading to an increase in cartel detection rates over time (European Commission 2005). We controlled for this effect using year fixed effects in columns (2-4) of Table 3 and a time trend variable (untabulated results). Second, we redefined LENIENCY as the percentage of cartel members that participated in the leniency program (see Table 4). Third, using data from Dong et al. (2014), we controlled for the existence of leniency provisions in the national competition laws of countries in which cartel members are incorporated.
} 
Second, we control for the cartel's organizational structure. Repeat offenders can help set up effective coordination mechanisms because they have previously formed cartels; however, they likely experience higher scrutiny from external parties (De 2010). We use an indicator variable that equals 1 if a cartel member is a repeat offender and 0 otherwise (REPEAT). We also control for the total number of members in a given cartel (\#MEMBER). While theory predicts that cartel duration should decrease with the number of cartel members, empirical evidence is ambiguous (Stigler 1964; Posner 1970). Third, we use the log of total assets SIZE as a proxy for firm size. Larger firms face higher reputational losses due to cartel detection and have greater incentives to monitor cartel activities. Fourth, cartel stability may decrease because cartel members may not be able to differentiate exogenous macroeconomic shocks from actual cheating behavior (Green and Porter 1984; Suslow 2005). To control for macroeconomic shocks, we use GDP growth data from the World Bank.

To examine whether reporting transparency affects cartel duration, we first conduct a univariate test and compare the mean cartel duration of firms with different levels of financial reporting transparency. We find that the mean duration for firms that report transparently (9.48 years) is significantly lower than that of opaque reporters (11.37 years; t-stat. 5.43). This result supports hypothesis 1 and suggests that reporting transparency decreases cartel duration through earlier detection of cheating.

Table 3, column (1) reports the results of eqn. (1). We find a positive and significant coefficient of our proxy for financial reporting transparency (coeff. 0.666; z-stat. 2.04). This finding confirms that higher reporting transparency reveals cartel member cheating, which destabilizes cartels. To assess the economic significance of our results, Figure 1 plots the Kaplan-Meier failure function, showing the probability to failure over time. The failure functions are based on the Cox regressions estimated for high and low reporting transparency groups. Furthermore, we standardize values of the covariates reported in column (1) of Table 3 to assess the difference in failure rates between the reporting transparency groups for an average cartel firm. Figure 1 shows that cartels with high reporting transparency are generally more likely to fail in the next year than those with low reporting transparency. Furthermore, the probability of failure increases over time for both groups. The difference in failure rates for high- and 
low-transparency cartels ranges between 11 percentage points when the cartel duration is 6 years (lower quartile of duration) and 26 percentage points when the cartel duration is 14 years (upper quartile of duration).

\section{- Insert Table 3 and Figure 1 about here -}

For our control variables, we find a negative coefficient on LENIENCY (coeff. -1.101, z-stat. 2.82), supporting the prediction that the use of the leniency policy by cartel members increases cartel duration. Furthermore, levied fines prolong the lives of cartels by increasing the costs of breaking them up (coeff. 0.189, z-stat. 2.09). While the coefficients on the other control variables have the predicted signs, they are not significant at the conventional level in all of the specifications.

To alleviate concerns that our results are driven by time-invariant characteristics, we control in column (2) for country, industry (based on the Fama-French 10-industry classification), and year fixed effects. $^{12}$ We still find a positive coefficient on FRT in support of our prior findings. Next, to assess whether unobserved firm heterogeneity affects our results, we use an OLS model with firm fixed effects. $^{13}$ Untabulated results reveal that cartel time span is 21 percent lower for firms that report transparently than for opaque reporters (t-stat. 1.71).

Next, we subject our tests to some alternative explanations and augment eqn. (1) with a set of additional control variables. Because the number of observations varies depending on the additional data requirements, we report results after including these control variables one at a time. First, both industry dynamics and the presence of new entrants affect the competitive environment and influence cartel sustainability (Lipczynski et al. 2005; Tirole 1988). For example, a low number of industry peers makes monitoring and initializing collusion easier. In turn, if a cartel cannot prevent new firms from entering the industry or cannot force them to join the cartel, new entrants will increase the industry output, sell at a price below that set by the cartel, and win the market share of the cartel firms, eventually leading to the

\footnotetext{
${ }^{12}$ Including country fixed effects does not allow us to identify the effects of countries with a small number of data points. Therefore, we replicated our results using countries with at least 20 data points. We also replicated the results using more granular industry classifications according to the 12-, 17-, 30-, 38-, 48-, and 49-industry groupings in Fama and French (1997). These additional tests did not change the inferences of our analysis.

${ }^{13}$ The Cox firm fixed effects model did not achieve convergence because of collinearity. However, we were able to estimate the Cox random effects model, an alternative way of controlling for unobserved firm heterogeneity. The estimated coefficient on FRT is 0.666 (z-stat. 1.97).
} 
cartel's breakdown. We capture industry dynamics and the presence of new entrants using the percentage change in aggregate industry sales based on the Worldscope sample of public firms from the 25 sample countries $\left(\triangle I N D \_S A L E S\right) .{ }^{14}$

Second, the international expansion of cartel firms reduces group homogeneity within the cartel, thereby destabilizing it (Pindyck 1977). Additionally, international expansion is correlated with following internationally recognized accounting standards. We use firm-level changes in the percentage of foreign sales ( $\left.\triangle F O R E I G N \_S A L E S \%\right)$ to control for international expansion. ${ }^{15}$ Third, we employ controls for the local antitrust enforcement and use the cartel member's country’s annual cartel detection rate (LOCAL_ENF), based on Connor (2014). Fourth, the results in González et al. (2015) show that governance mechanisms affect price fixing. We control for cross-country variation in investor protection and classify countries into high- versus low-investor protection regimes, using the median split of the anti-director-rights index (La Porta et al. 1998). This analysis omits 14 cartel firm years due to the unavailability of the anti-director-rights index for the Czech Republic, Hungary, and Luxembourg.

The results of columns (3) to (6) of Table 3 show that industry dynamics, international expansion, and high governance standards destabilize cartels. Importantly, controlling for observable factors that affect cartel duration and may correlate with reporting transparency does not affect our inferences.

We find a negative association between reporting transparency and cartel duration using data of publicly quoted cartel members. To replicate our analysis at the cartel level, we use eqn. (1) and define variables at the cartel level by calculating their average values for each cartel or cartel year. ${ }^{16}$ Table 4 panel A, uses 391 data points and reports the results of the cartel-year analysis. We are interested in the coefficient on FRT_CARTEL, the percentage of cartel members that report under IFRS or U.S. GAAP in a given year. We find a positive and statistically significant coefficient (coeff. 2.458, z-stat. 1.85), which is

\footnotetext{
${ }^{14}$ Our results are qualitatively similar when we proxy for industry dynamics using (the change in) the number of industry peers, industry growth opportunities (the change in the industry book-to-market ratio), and entry barriers (the industry ratio of fixed assets to total assets).

${ }^{15}$ Using anticipated international expansion (future foreign sales) in an untabulated sensitivity analysis does not change our inferences.

${ }^{16}$ Because we do not have data on the total assets of private firms, our cartel-level analysis either excludes or redefines variables that use total assets. We also have no data on the accounting frameworks of private firms. However, because none of the EU countries allowed the voluntary adoption of IFRS for the individual accounts of private firms during our sample period, we infer that private firms must have used local GAAP. All U.S. cartel members are public firms.
} 
robust to inclusion of industry fixed effects (coeff. 3.259, z-stat. 1.83). This result confirms both our prior results and hypothesis 1 .

$$
\text { - Insert Table } 4 \text { about here - }
$$

We now, turn to the cartel-level data $(\mathrm{N}=98)$ and estimate the model using the simplest form of the Cox proportional hazard model, where the dependent variable is cartel duration, and the independent variables are time-invariant cartel characteristics (see Cleves et al. 2008). We exploit cross-sectional differences in the transparency of local GAAP relative to U.S. GAAP and IFRS. Redefining our test variable in such a way allows for a more granular measurement of reporting transparency.

We consider 17 reporting and disclosure requirements from Bae et al. (2008), which are treated similarly under IFRS and U.S. GAAP. We then determine whether local GAAP mandates rules different from those under IFRS and U.S. GAAP. These differences stem from greater disclosure requirements under IFRS and U.S. GAAP and from the existence of local GAAP measurement rules that can lead to opaque financial statements and offer potential for earnings management. We define GAAP_DIFF as the negative average distance (i.e., number of differences) of cartel members' local GAAP from IFRS and U.S. GAAP, based on the country scores from Bae et al. (2008). Values of this variable close to zero indicate that cartel members are on average required to use transparent accounting rules (i.e., rules similar to those of U.S. GAAP and IFRS). Table 4, panel B, reports a positive and significant coefficient on GAAP_DIFF (coeff. 0.073, z-stat. 2.30), suggesting that reporting transparency lowers cartel duration.

\section{Test of Hypothesis 1a: Transparency, Cheating, and Cartel Duration}

Our previous results show that reporting transparency is associated with lower cartel duration, consistent with the role of transparency in cheating discovery. We next provide direct evidence on the role of cheating in mediating the relationship between transparency and cartel duration. Hypothesis 1a predicts that financial reporting transparency decreases cartel duration when cheating occurs and more so when cheating is widespread, while transparency increases cartel duration when cartel firms do not cheat. We expect cheating to be more likely in cartels that (a) do not use a trade association to police the cartel 
agreement or coordinate the cartel's response to cheating, (b) have low excess capacity, and (c) have high profit heterogeneity.

To test hypothesis 1a, we augment eqn. (1) with a new variable that proxies for the likelihood of cheating (CHEAT), and an interaction between this new variable and FRT. (While we report results for the parsimonious model, our inferences do not change when we control for other determinants of cartel duration from Table 3.) In this set-up, the coefficient on FRT measures the association between reporting transparency and cartel duration when cheating is relatively unlikely (i.e., CHEAT $=0$ ). Because we expect transparency to lead to contracting benefits when cheating is unlikely, we predict the $F R T$ coefficient to be negative. The coefficient of the interaction term $F R T \times C H E A T$ shows the incremental effect of reporting transparency on cartel duration for cartels that are more likely to incur cheating. Because transparent reporting decreases cartel duration when cheating occurs, and more so when cheating is widespread, we predict a positive coefficient on FRT $\times C H E A T$. We do not predict how cheating affects cartel duration when cheating cannot be uncovered due to opaque reporting (i.e. coefficient on CHEAT). However, our three cheating proxies are negatively correlated with cartel duration (average $\rho-0.102$ and t-stat. 3.25), indicating that overall cheating (i.e. for cartels with high and low financial reporting transparency) destabilizes cartels.

We obtain information from the Reports on the use of a trade association, finding that 22 percent of the cartels use one. The variable CHEAT equals 1 if the cartel does not use a trade association, and 0 otherwise. Table 5, column (1) shows that the reduction in cartel duration for transparent cartels is more pronounced when the likelihood of cheating is high than when it is low (coeff. 1.980, z-stat. 1.91). While transparent reporting decreases cartel duration when the likelihood of cheating is high (coeff. $-0.313+$ $1.980=1.667$ ), we find that transparent reporting is associated with an increase in cartel duration when cartels use a trade association to counteract cheating (coeff. -0.313). Although the increase in cartel duration for cartels that use a trade association is not significant at the conventional level, the sign of the coefficient suggests that reporting transparency may provide contracting benefits in the cartel setting when cheating is relatively unlikely. 
We next use two continuous variables to proxy for the extent of cheating. First, because cartel members can invest in excess capacity to retaliate when another cartel member cheats, column (2) investigates abnormal increases in inventory. We now define CHEAT as the average change in inventory holdings (scaled by total assets) of cartel members less the average change in inventory holdings (scaled by total assets) of firms outside of the cartel, matched by industry, country, and year. While taking the first difference in inventory holdings controls for firm-specific inventory levels, subtracting industry-wide changes controls for inventory changes over the business cycle. We multiply the variable by -1 , so that higher values of the variable (lower excess capacity) increase cheating rates. Second, column (3) reports the results for cartels with heterogeneous profitability, because differences in profitability levels within the cartel provide incentives for cheating. We redefine CHEAT in column (3) as the standard deviation of EBIT over total assets for each cartel and year. ${ }^{17}$

We find a positive and significant coefficient on the interaction term FRT $\times$ CHEAT (column 2: coeff. 0.343, z-stat. 2.03; column 3: coeff. 0.497, z-stat. 2.06): Transparent reporting is associated with a greater decrease in cartel duration when the likelihood of cheating increases. These results support hypothesis 1a and suggest that transparent reporting reduces cartel duration by revealing cheating.

The coefficients on FRT in columns (2) and (3) capture the effect of reporting transparency on cartel duration when the cheating proxy equals zero. At this level, the coefficient on FRT in column (3) is predictably negative, albeit not significant (coeff. -0.601 , z-stat. 0.50), while it is positive and significant in column (2) (coeff. 1.553, z-stat. 2.53). Although this positive coefficient is not consistent with our predictions, it is likely attributable to the effect of FRT being measured at zero, which-in case of excess capacity — represents the median value of this variable (see Table 2). In turn, column (1) measures the effect of FRT for those $22 \%$ of cartels that are relatively unlikely to cheat (i.e. cartels with a trade association), while column (3) measures the effect of $F R T$ for the minimum value of the cheating proxy (i.e., standard deviation of profits is zero). To the extent that cheating is still prevalent for the median

\footnotetext{
${ }^{17}$ In this analysis, we do not use cartels with three or fewer cartel members.
} 
cartel in our sample, the resulting decrease in cartel duration may overshadow any contracting benefits of transparent reporting and explain why we find a positive coefficient on FRT in column (2).

As with our tests in the previous section, we validate results of our cross-sectional tests by using the cartel year as the unit of analysis. To increase the power of our tests, we construct a summary measure of propensity to cheat based on our three cheating proxies. CHEAT now equals 1 if a cartel does not use a trade association and has low excess capacity and has heterogeneous cost structures in a given year. CHEAT equals 0 for all other cartel years. To ensure that we have a sufficient number of observations in each category, we assign our two continuous variables into tertiles and use observations from the second and the third tertiles to identify cartels with the relatively high likelihood of cheating. ${ }^{18}$ Then we augment the cartel-year analysis from Table 4, panel A, by including FRT $\times C H E A T$, where FRT is the percent of cartel members that report under IFRS or U.S. GAAP. Different from Table 4, we use only public cartel firms for which we have data on all three cheating proxies. We find that the coefficient on the interaction term $F R T \times C H E A T$ remains positive and significant (coeff. 8.967, z-stat. 2.07), while that on FRT is not significant at the conventional level.

Overall, our findings suggest that reporting transparency influences the outcomes of non-enforceable cartel agreements by allowing the cartel members to more effectively monitor the adherence to the agreement. However, our results do not rule out the role of reporting transparency in facilitating contracting, as any contracting benefits of reporting transparency in our sample may be overshadowed by cheating.

\section{Test of Hypothesis 2: Segment Reporting and Cartel Duration}

We next examine the attributes of transparent accounting standards that can affect cartel duration. Both to verify self-reported sales figures and to detect cheating, cartels require segment sales data. We expect that IFRS and U.S. GAAP firms will report segment data more transparently than local GAAP, due to differences in segment disclosure requirements between IFRS or U.S. GAAP and local GAAP.

\footnotetext{
${ }^{18}$ As a result, we code 63 percent of observations as cartels with relatively high likelihood of cheating $(C H E A T=1)$, and 37 percent of observations as cartels with relatively low likelihood of cheating $(C H E A T=0)$. This split is consistent with Levenstein and Suslow (2006) and Eckbo (1976) who finds that 60 percent of cartels in their samples are affected by member cheating.
} 
Furthermore, in line with our previous results, we expect cartels with more transparent segment disclosure to have lower durations.

To analyze whether IFRS and U.S. GAAP require greater segment disclosure than local GAAP, we use the number of reported segments from Worldscope as a proxy for segment reporting transparency (Cho 2015). Table 6 panel A, compares the mean number of reported business segments of firms that follow transparent accounting standards to that of firms reporting under local GAAP. We conduct this test for three different sub-samples: (1) the full sample, (2) the sample of IFRS vs. local GAAP firms, and (3) a sample of firms that switch from local GAAP to IFRS. This third test controls for cross-sectional heterogeneity in segment reporting practices and uses each firm as its own control. In all three cases, we find that IFRS and U.S. GAAP increase the number of reported business segments relative to local GAAP, possibly explaining why we find lower cartel durations for firms following transparent accounting standards.

To show that segment disclosures affect cartel duration, we use eqn. (1) after substituting the proxy for segment transparency SEGTRANS for FRT. We define SEGTRANS as the average segment number reported by all cartel members in a given year. ${ }^{19}$ Table 6 panel B, reports the results of this analysis. We find a negative association between the number of segments and cartel duration (coeff. 0.298; z-stat. 2.32). This result is consistent with segment disclosures that allow cartel members to detect cheating by either providing enough information to infer cartel-market sales or directly reporting cartel-market sales.

\section{- Insert Table 6 about here -}

González et al. (2013) find that cartel firms use their discretion in the classification of business segments and frequently reclassify segments to misguide readers of financial statements. For example, they report on the case of a cartel member Bristol-Myers Squibb Co., which constantly reorganized business segments into different subcategories before eliminating such disclosures for a number of years. Because firms can use segment reclassifications to hide cheating, we use segment reclassifications as our

\footnotetext{
${ }^{19}$ We obtain qualitatively similar results when we use the log of the segment number reported by firm $i$ in year $t$ as our firm-specific measure of segment transparency. Furthermore, the results hold when we use a proxy based on handcollected data and a more granular definition of firm business segments discussed on the next page.
} 
measure of reporting opacity and hand-collect information from annual reports on segment reporting practices.

Our data collection reveals that cartel firms frequently provide a two-layered disclosure of business segments: broadly defined business segments (collected by Worldscope) and more narrowly defined ones. More narrow segment reporting should provide a better means of verifying self-reported sales within a cartel. Importantly, we observe that about a quarter of sampled firms disclose sales data for their share of the cartel market as one of their narrowly defined business segments. To examine how firms change the presentation of their business segments, we track the disclosures of narrowly defined business segments over time and code changes in the presentation of business segments.

We code a change in the presentation format when a firm changes the categories of business segments while maintaining their total number. For example, British Airways-a member of the “Airfreight” cartel—reclassified "Scheduled service passenger," "Scheduled service freight and mail,” and “Non-scheduled services” into "Network airline business," "Regional airline business,” and "Nonairline business.” Furthermore, the presentation format changes when a firm reorganizes its segments into a different number of subcategories. For example, Danone-a member of a beer cartel—merged two segments, “Beer” and “Mineral Water," into one segment, "Beverages.” While using hand-collected data leads to a lower sample size because we are not able to retrieve financial statements for all firm-years, this analysis exploits the important aspect of reporting practice in the cartel setting and allows us to observe the actual reclassifications between the business segments.

We find a 49 percent chance that at least one cartel firm reclassifies its business segments in a given year, thus reducing the overall transparency in the cartel. Because constant reclassifications of business segments increase opacity, we redefine SEGTRANS as the average number of segment reclassifications for a given cartel over its lifespan and multiply it by -1 , so that higher (lower) values of this variable indicate greater (lower) reporting transparency. Table 6 panel B shows that cartels with a lower number of reclassifications and greater segment transparency exhibit lower cartel duration (coeff. 2.378; z-stat. 
2.74). This result confirms our previous findings for the number of reported segments and supports hypothesis 2 .

To examine whether transparent accounting standards affect cartel duration by any means other than transparent segment disclosures, we augment the models estimated in Table 6 panel $\mathrm{B}$, with FRT. Untabulated results show an incrementally positive and significant coefficient on FRT when we control for differences in segment disclosures. This result suggests that transparent reporting standards may lower cartel duration because they can reveal cheating through the provision of comparable information and/or reduction in earnings management.

Finally, we test hypothesis 2 using cartel-level data. We use variation in the requirement for reporting business and geographic segments in the country in which the cartel firm is domiciled, based on data in Bae et al. (2008). We define $S E G \_R E Q$ as the percentage of cartel members based in countries requiring segment reporting under local GAAP. This alternate proxy exploits the fact that the disclosure requirements are exogenous to the cartel firms, thereby alleviating the concern that cartel firms choose the reported number of business segments. Furthermore, because our previous tests show that segment reclassifications play an important role in the cartel setting, we use cartel-level data to replicate previously reported results on segment reclassifications. Table 6 panel C shows that cartels have lower duration both when cartel members face mandatory segment reporting requirements (coeff. 1.557, z-stat. 3.68) and when cartel members reclassify segments less frequently (coeff. 2.517; z-stat. 3.32).

\section{SELECTION BIAS AND ENDOGENEITY ISSUES}

\section{Selection Bias Due to Voluntary IFRS Adoption}

Our main finding that reporting transparency affects cartel duration may be due to an omitted variable bias, because we use a nonrandom sample of cartels and use firms that choose to report under IFRS. In this section, we control for these selection biases.

Our analysis includes firms that have a choice of voluntarily adopting IFRS. As a result, we cannot rule out the possibility that unobservable cartel characteristics affect voluntary adoption and the break-up 
of a cartel. We control for the endogeneity of IFRS adoption similarly to previous literature (Leuz and Verrecchia 2000; Müller et al. 2015). We estimate a two-stage model, with the first stage estimating the likelihood of voluntary IFRS adoption based on firm-specific characteristics that affect firm decision to adopt IFRS, and the second stage using the estimates from the first-stage model to correct for the endogeneity of IFRS adoption. Consistent with the literature that explains voluntary adoption of nonlocal GAAP, we postulate that the decision to adopt IFRS is a function of financing needs (proxied by capital intensity), capital market pressure (proxied by disperse ownership structure), and firm size (log of total assets) (see Cuijpers and Buijink 2005; Leuz and Verrecchia 2000).

The exclusion restriction of our two-stage model requires us to identify at least one independent variable that increases the likelihood of IFRS adoption, but that does not affect cartel duration in the second stage, except through its impact on IFRS adoption (Lennox et al. 2011). Ownership dispersion plausibly satisfies the exclusion restriction, because dispersed ownership increases the demand for transparent accounting information under IFRS. In untabulated tests, we find that ownership dispersion is positively correlated with the likelihood of IFRS adoption $(\mathrm{p}<0.01)$. At the same time, because “expendable” middle managers coordinate cartel operations and not the firm shareholders (Ashton and Pressey 2012), the ownership structure is less likely to directly affect cartel duration. Because the effectiveness of our identification strategy depends on this conjuncture, we next report an alternative approach of dealing with the endogeneity of IFRS adoption, an approach that does not require us to use a two-stage model.

Because endogeneity is a concern only for firms that can choose an accounting framework (as opposed to those required to follow local GAAP or U.S. GAAP), we endogenize the decision to report under IFRS or local GAAP in countries where voluntary IFRS adoption was common. First, we identify three countries from Daske et al. (2013) where the choice to report under IFRS or local GAAP was common and at least 10 percent of firms listed in each country voluntarily adopted IFRS: Germany, Luxembourg, and Switzerland. Second, we use all non-cartel firms from these three countries to examine how their decision to adopt IFRS is affected by ownership dispersion, capital intensity, and firm size. 
This first-stage probit model estimates the weights that non-cartel firms assign to different observable determinants of IFRS adoption. Estimating the probit model out of sample allows us to rule out the possibility that cartel characteristics that lead to both IFRS adoption and cartel coordination could affect the model estimates (Christensen et al., 2007, use a similar approach).

Third, we use the weights obtained from the probit model to estimate the probability of IFRS adoption for our sample of cartel firms choosing voluntary adoption. Our use of predicted values from the first-stage probit regression is econometrically equivalent to augmenting the second-stage stage regression with the inverse Mills ratio (IMR). ${ }^{20}$ Using predicted values and out-of-sample estimates in our setting has an intuitive appeal: We want to know whether a non-cartel firm, given specific characteristics, is likely to adopt IFRS. We then "force" the cartel firm to make a similar decision to that of a firm that has similar characteristics but that does not need to consider any cartel-related costs of its decision to adopt IFRS. The identification here is achieved through (a) the use of at least one firm characteristic (ownership dispersion) that is less likely to directly affect cartel duration and (b) the fact that the weights cartel firms assign to individual firm characteristics are unaffected by cartel considerations.

We reestimate column (2) of Table 3 after substituting FRT_PROB for FRT. FRT_PROB equals 1 for firms that face a mandatory requirement to report under U.S. GAAP, a predicted out-of-sample probability of voluntary adoption for firms that had a choice between IFRS and local GAAP (probability values range between 0 and 1), and 0 for firms that report under local GAAP and cannot report under IFRS. $^{21}$ Table 7, column (1), reports the results for the model that endogenizes the decision to follow IFRS. After controlling for the endogenous nature of IFRS adoption, we find that transparent reporting reduces cartel duration (coeff. 1.797, z-stat. 2.23). Because we next use U.S. firms in a separate analysis,

\footnotetext{
${ }^{20}$ Maddala (1983) shows that both approaches are equivalent. Leuz and Verrecchia (2000) use predicted values from the first-stage probit model in the context of voluntary IFRS adoption and Müller et al. (2015) use predicted values to control for the endogeneity of the decision to recognize or disclose certain information. We note that we obtain qualitatively similar results when we estimate the first-stage probit model within the sample of cartel firms and use the IMR in the second-stage model.

${ }^{21}$ Our sample includes eight firm-year observations from the mandatory IFRS adoption period (2005). As all of these firms reported voluntarily under IFRS before the mandatory adoption period, each firm chose to adopt IFRS early. Therefore, using the estimated out-of-sample probabilities, we endogenize the decision to report under IFRS for these firms.
} 
column (2) examines whether our results are solely attributable to U.S. firms. We find qualitatively similar results after excluding U.S. firms from the sample (coeff. 1.915, z-stat. 1.81).

$$
\text { - Insert Table } 7 \text { about here - }
$$

As an alternative strategy to controlling for the endogeneity of IFRS adoption, column (3) shows that our results hold when the accounting framework is exogenously determined (i.e., for firms that cannot choose their accounting framework). This analysis compares the cartel duration of firms required to follow U.S. GAAP to that of firms following local GAAP in countries with no choice of switching to IFRS. We substitute USGAAP for FRT, and set USGAAP to 1 if a firm follows U.S. GAAP and to 0 if it follows local GAAP. We find that transparent reporting under U.S. GAAP lowers cartel duration (coeff. 21.589, z-stat. 6.83). ${ }^{22}$ While greater cartel enforcement in the U.S. may also lead to a positive coefficient on USGAAP, we obtain qualitatively similar results when we control for the effectiveness of cartel prosecution in different countries by using both the antitrust enforcement score, which captures managers' views about the quality and the effectiveness of national antitrust regulations (see Global Competitiveness Reports, Schwab et al. 2007), and the number of prosecuted cartel cases in a given country and year (Connor 2014). ${ }^{23}$

\section{Selection Bias Due to Sampling of Indicted Cartels}

The sample in our analysis is not random, because it omits firms that participated in the cartel but were not indicted for their anticompetitive behavior. To control for the selection bias, we use the twostage Heckman estimation method. In the first stage, we model the likelihood of being indicted by the

\footnotetext{
22 The estimated coefficient is substantially higher than the effect of FRT in Table 3, possibly indicating that the proportional hazards assumption was violated (Box-Steffensmeier and Christopher 2001) or that the model fails to account for the unobservable firm heterogeneity. To control for misspecification of the hazard model and for the unobservables, we use an OLS model with firm random effects, which allows us to estimate the coefficient on the time invariant USGAAP. We find that cartel duration decreases by 23 percent (p-value $<0.1$ ) when a firm follows U.S. GAAP, a finding in line with our main results.

${ }^{23}$ The U.S. Department of Justice notes that cartels fear prosecution in the U.S. and therefore avoid involving U.S. subjects or meeting in the U.S. For example, a non-U.S. member of the "Lysine Cartel" opposed holding its next cartel meeting in Hawaii because the U.S. "is very severe for the control of antitrust activity" (Griffin 2000). These concerns were justified because the FBI videotaped the meeting, and these materials were later used as key pieces of evidence for prosecuting the cartel. We note, however, that we examine cartels prosecuted by the EC, and thus U.S. enforcement can affect our results only if U.S. authorities start an independent investigation and tip off the EC about possible cartels. EC reports that only 4 percent of its cartel investigations were initiated as a result of a tip-off from local cartel authorities and other institutions.
} 
EC, that is, the likelihood of being included in our main test sample. Then, to control for the omitted variable problem, we include the estimate of the IMR (MILLS) as an additional explanatory variable in eqn. (1) (Heckman 1979).

$$
\begin{aligned}
\operatorname{Prob}(\text { Detect }=1) & =\alpha_{0}+\beta_{1} D I S T_{i}+\beta_{2} S I Z E_{i t}+\beta_{3} S A L E S_{-} G R O W T H_{i t} \\
& +\beta_{4} R O A_{i t}+\text { Fixed Effects }+\varepsilon_{i t}
\end{aligned}
$$

Eqn. (2) is a probit regression that models the likelihood of being indicted by the EC. The dependent variable (DETECT) equals 1 for all cartel firm years and 0 for the (non-cartel) control firms. To approximate as closely as possible those firms that may have participated in unobservable cartels (i.e., cartels that did not break-up, that were not indicted, or both), we use control firms that are similar to our cartel firms in a number of important characteristics. We match firms on country, industry, time period and size, resulting in 1,072 control firm year observations. In the additional analysis, we more closely identify control firms that colluded but were not indicted or destabilized due to lax competition enforcement in their home country. We do so by using the median antitrust enforcement score to further restrict the control sample to firms from countries with low antitrust enforcement.

We use the minimum geographic distance between the cartel firms' headquarters and the EC (DIST) to fulfill the exclusion restriction of our two-stage model, because the proximity of a firm to its regulator affects the effectiveness of regulation and the likelihood of cartel detection (DeFond et al. 2011) without having any direct effect on cartel duration. For example, Kedia and Rajgopal (2011) find that regulation is most effective when it is local. Table 8 shows that the proximity to the regulator increases the likelihood of indictment. At the same time, that the distance from a certain geographic point can somehow make cartels inherently (un)stable is highly unlikely. As a result, the distance to the EC should not have a direct effect on cartel duration (i.e., it can affect cartel duration only through its impact on cartel detection).

Eqn. (2) further controls for firm size SIZE, because larger firms are more visible to the regulator, competitors, and consumers, thereby increasing the likelihood of informal complaints. We use the firm's sales growth (SALES_GROWTH), which may signal abnormally high product prices set by the cartel agreement. The firm's return on assets $(R O A)$ measures profitability, which may reveal that a firm is 
abusing its market power. Moreover, to control for time-invariant industry and year-specific effects, we include industry and year fixed effects.

$$
\text { - Insert Table } 8 \text { about here - }
$$

Table 8, column (1), displays the results using matched control firms from all possible countries, whereas column (2) displays the results using matched control firms from low antitrust enforcement countries. When we control for selection bias by using the IMR, we continue to find that transparent reporting reduces cartel duration (column (1): coeff. 1.020, z-stat. 1.92; column (2): coeff. 1.037, z-stat. 2.01).

Alternatively, by performing a sub-sample analysis that uses cartels that were not broken up by the regulator, we rule out the role of competition authorities in breaking up the cartels. We identify these cases by including only cartels that ended before the start of the EC investigation. Using the sub-sample of cartels that terminated due to natural causes, we find that the coefficient on FRT is positive and statistically significant.

\section{SUMMARY AND DISCUSSION}

This study investigates whether reporting transparency affects product market coordination and competition. We hypothesize that cartels following U.S. GAAP or IFRS exhibit higher reporting transparency through segment reporting. We posit that greater transparency may increase cartel duration

by reducing contracting costs. Alternatively, greater transparency may decrease cartel duration by facilitating the detection of cheating behavior, thus increasing the cartel's cost of deterrence or the likelihood of a price war when cartel members cheat and the cartel lacks effective ways of responding to cheating.

Our results show that transparent reporting under U.S. GAAP and IFRS is associated with lower cartel duration, and that result is (partly) explained by the greater transparency of segment disclosures. Our cross-sectional tests show that the decrease in cartel duration under transparent reporting is more pronounced for cartels with a high likelihood of cheating than for cartels with a low likelihood of cheating. These findings suggest that transparent reporting prevents welfare-reducing coordination 
among firms, through earlier detection of cheating cartel members. While results support the role of reporting transparency in cheating discovery, we find inconclusive results for contracting benefits of transparency in the cartel setting - possibly due to the low power of our tests, which try to "switch off" the effect of cheating.

Our results remain robust to the use of transparency measures that are not affected by the choice of reporting under IFRS. We also control for the selection bias resulting from our sample's consisting of indicted cartels. This self-selection control allows us to estimate an unbiased effect of reporting transparency on cartel duration for "observable” cartels that collapsed—an economically significant cartel population.

Our study is the first to empirically analyze the effect of accounting disclosures on product market competition, thereby making three contributions to the literature. First, while the disclosure literature examines how product markets shape accounting disclosures, we show that the reverse effect is possible and that transparent disclosures can shape product market outcomes. Second, our study contributes to the literature on the verification role of audited financial statements by showing that the verification role of audited financial reporting extends to non-enforceable contracts. Third, we add to the anti-trust literature by modeling the effect of reporting transparency on cartel duration. Because reducing cartel duration decreases the deadweight loss induced by dampened product market competition, our results have important implications for antitrust authorities. Additionally, our results point to spillover effects between capital market regulation and product markets, and show that improvements in reporting transparency and enforcement can complement competition policy. 


\section{REFERENCES}

Abreu, D., P. Milgrom, and D. Pearce. 1991. Information and timing in repeated partnerships. Econometrica 59 (6):1713-1733.

Abreu, D., D. Pearce, and E. Stacchetti. 1986. Optimal cartel equilibria with imperfect monitoring. Journal of Economic Theory 39 (1):251-269.

Alpert, L. I., and A. MacDonald. 2013. Potash company's chief sticks to strategy. Wall Street Journal, July 31.

Asch, P., and J. J. Seneca. 1976. Is collusion profitable? Review of Economics and Statistics 58 (1):1.

Ashton, J. K., and A. D. Pressey. 2012. Who manages cartels? The role of sales and marketing managers within international cartels: Evidence from the European Union 1990-2009. Working Paper, Bangor Business School and Birmingham Business School.

Athey, S., and K. Bagwell. 2001. Optimal collusion with private information. RAND Journal of Economics:428-465.

Bae, K. H., H. Tan, and M. Welker. 2008. International GAAP differences: The impact on foreign analysts. The Accounting Review 83 (3):593-628.

Bagnoli, M., and S. G. Watts. 2010. Oligopoly, disclosure, and earnings management. The Accounting Review 85 (4):1191-1214.

Ball, R., R. M. Bushman, and F. P. Vasvari. 2008. The debt-contracting value of accounting information and loan syndicate structure. Journal of Accounting Research 46 (2):247287.

Ball, R., S. Jayaraman, and L. Shivakumar. 2012. Audited financial reporting and voluntary disclosure as complements: A test of the confirmation hypothesis. Journal of Accounting and Economics 53 (1):136-166.

Barth, M. E., Y. Konchitchki, and W. R. Landsman. 2013. Cost of capital and earnings transparency. Journal of Accounting and Economics 55 (2-3):206-224.

Barth, M. E., W. R. Landsman, and M. H. Lang. 2008. International accounting standards and accounting quality. Journal of Accounting Research 46 (3):467-498.

Berger, P. G., and R. N. Hann. 2007. Segment profitability and the proprietary and agency costs of disclosure. The Accounting Review 82 (4):869-906.

Bertomeu, J., J. H. Evans, M. Feng, and A. Tseng. 2015. Tacit collusion and voluntary disclosure: Theory and evidence from the U.S. automotive industry. Working paper, University of California, San Diego (UCSD).

Beyer, A., D. A. Cohen, T. Z. Lys, and B. R. Walther. 2010. The financial reporting environment: Review of the recent literature. Journal of Accounting and Economics 50 (2-3):296-343.

Bhattacharya, U., and H. Daouk. 2002. The world price of insider trading. Journal of Finance 57 (1):75-108.

Box-Steffensmeier, J. M., and J. W. Z. Christopher. 2001. Duration models and proportional hazards in political science. American Journal of Political Science 45 (4):972-988.

Brenner, S. 2009. An empirical study of the european corporate leniency program. International Journal of Industrial Organization 27 (6):639-645.

Brochet, F., A. D. Jagolinzer, and E. J. Riedl. 2013. Mandatory IFRS adoption and financial statement comparability. Contemporary Accounting Research 30 (4):1373-1400.

Bundeskartellamt. 2011. Fuel sector inquiry. Final Report in accordance with § 32e GWB. 
Burgstahler, D., C. Leuz, and L. Hail. 2006. The importance of reporting incentives: earnings management in European private and public firms. The Accounting Review 81 (5):9831016.

Bushman, R. M., J. D. Piotroski, and A. J. Smith. 2011. Capital allocation and timely accounting recognition of economic losses. Journal of Business Finance and Accounting 38 (1-2):133.

Byard, D., Y. Li, and Y. Yu. 2011. The effect of mandatory IFRS adoption on financial analysts' information environment. Journal of Accounting Research 49 (1):69-96.

Cabral, L. B. 2005. Collusion theory: Where to go next? Journal of Industry, Competition and Trade 5 (3-4):199-206.

Caudill, S. B., and F. G. Mixon. 1994. Cartels and the incentive to cheat: Evidence from the classroom. The Journal of Economic Education 25 (3):267-269.

Cho, Y. J. 2015. Segment disclosure transparency and internal capital market efficiency: Evidence from SFAS No. 131. Journal of Accounting Research 53 (4):669-723.

Christensen, H. B., E. Lee, and M. Walker. 2007. Cross-sectional variation in the economic consequences of international accounting harmonization: The case of mandatory IFRS adoption in the UK. The International Journal of Accounting 42 (4):341-379.

Cleves, M. A., W. Gould, and R. Gutierrez. 2008. An introduction to survival analysis using Stata. Texas: Stata Press.

Connor, J. M. 2001. Global price fixing: Our customers are the enemy: Kluwer Academic Publishers.

. 2004. Global antitrust prosecutions of modern international cartels. Journal of Industry, Competition and Trade 4 (3):239-267.

- 2014. The private international cartels (PIC) data set: Guide and summary statistics, 1990-2013. Working paper, American Antitrust Institute (AAI).

Cox, D. R. 1972. Regression models and life-tables. Journal of the Royal Statistical Society. Series B (Methodological) 34 (2):187-220.

Cuijpers, R., and W. Buijink. 2005. Voluntary adoption of non-local GAAP in the European Union: a study of determinants and consequences. European Accounting Review 14 (3):487-524.

Daske, H., and G. Gebhardt. 2006. International financial reporting standards and experts' perceptions of disclosure quality. Abacus 42 (3/4):461-498.

Daske, H., L. Hail, C. Leuz, and R. Verdi. 2013. Adopting a label: Heterogeneity in the economic consequences around IAS/IFRS adoptions. Journal of Accounting Research 51 (3):495-547.

Datta, S., M. Iskandar-Datta, and V. Singh. 2013. Product market power, industry structure, and corporate earnings management. Journal of Banking and Finance 37 (8):3273-3285.

De, O. 2010. Analysis of cartel duration: Evidence from EC prosecuted cartels. International Journal of the Economics of Business 17 (1):33-65.

DeFond, M. L., J. R. Francis, and X. Hu. 2011. The geography of SEC enforcement and auditor reporting for financially distressed clients. Working paper, University of Southern California.

Dick, A. R. 1996. When are cartels stable contracts? Journal of Law and Economics 39 (1):241283.

Doblin, E. M. 1943. Accounting problems of cartels. The Accounting Review 18 (3):249-256.

Dong, A., M. Massa, and A. Žaldokas. 2014. Busted! Now what? Effects of cartel enforcement on firm value and corporate policies. Working paper, INSEAD.

Eckbo, P. L. 1976. Future of world oil. Cambridge: Ballinger Publishing. 
European Commission. 2005. Report on competition policy.

Fama, E. F., and K. R. French. 1997. Industry costs of equity. Journal of Financial Economics 43 (2):153-193.

Fink, N., P. Schmidt-Dengler, K. Stahl, and C. Zulehner. 2017. Registered cartels in Austria: an overview. European Journal of Law and Economics 44 (3):385-422.

Genesove, D., and W. P. Mullin. 2001. Rules, communication, and collusion: Narrative evidence from the sugar institute case. The American Economic Review 91 (3):379-398.

González, T. A., M. Schmid, and D. Yermack. 2013. Smokescreen: How managers behave when they have something to hide. Working paper, University of St. Gallen and New York University.

. 2015. Smokescreen: How managers behave when they have something to hide. Working paper, University of St. Gallen and New York University.

Green, E. J., and R. H. Porter. 1984. Noncooperative collusion under imperfect price information. Econometrica 52 (1):87-100.

Griffin, J. M. 2000. An inside look at a cartel at work: Common characteristics of international cartels, edited by U. S. D. o. J.-A. Division: U.S. Department of Justice.

Harrington Jr., J. E. 2006. How do cartels operate? In Foundations and trends in microeconomics. Hanover, MA: Now Publishers Inc., 1-105.

Harrington Jr., J. E., and M. H. Chang. 2009. Modelling the birth and death of cartels with an application to evaluating antitrust policy. Journal of the European Economic Association 7 (6):1400-1435.

Harrington Jr., J. E., and A. Skrzypacz. 2007. Collusion under monitoring of sales. The RAND Journal of Economics 38 (2):314-331.

- 2011. Private mononitoring and communication in cartels: Explaining recent collusive practices. American Economic Review 101 (6):2425-2449.

Harrington Jr., J. E., and Y. Wei. 2017. What can the duration of discovered cartels tell us about the duration of all cartels? The Economic Journal 127 (604):1977-2005.

Healy, P. M., and K. G. Palepu. 2001. Information asymmetry, corporate disclosure, and the capital markets: A review of the empirical disclosure literature. Journal of Accounting and Economics 31:405-440.

Heckman, J. J. 1979. Sample selection bias as a specification error. Econometrica 47 (1):153161.

Hölmstrom, B. 1979. Moral hazard and observability. The Bell Journal of Economics 10 (1):7491.

Hyytinen, A., F. Steen, and O. Toivanen. 2017. Anatomy of cartel contracts. Working paper, Norwegian School of Economics (NHH).

Jensen, M. C., and W. H. Meckling. 1976. Theory of the firm: Managerial behavior, agency costs and ownership structure. Journal of Financial Economics 3 (4):305-360.

Kedia, S., and S. Rajgopal. 2011. Do the SEC's enforcement preferences affect corporate misconduct? Journal of Accounting and Economics 51 (3):259-278.

Kim-Gina, J. 2018. External verifiability of accounting information and intangible asset transactions. Working paper, The Wharton School - University of Pennsylvania.

Kolasky, W. J. 2002. Coordinated effects in merger review: From dead frenchmen to beautiful minds to mavericks. Available at http://www.usdoj.gov/atr/public/speeches/11050.htm.

La Porta, R., F. Lopez-de-Silanes, A. Shleifer, and R. W. Vishny. 1998. Law and finance. Journal of Political Economy 106 (6):1113-1155.

Lambert, R. A. 2001. Contracting theory and accounting. Journal of Accounting and Economics 32 (1-3):3-87. 
Lang, M., K. V. Lins, and M. Maffett. 2012. Transparency, liquidity, and valuation: International evidence on when transparency matters most. Journal of Accounting Research 50 (3):729-774.

Lennox, C., J. R. Francis, and Z. Wang. 2011. Selection models in accounting research. The Accounting Review 87 (2):589-616.

Leslie, C. R. 2004. Trust, distrust, and antitrust. Texas Law Review 82 (3):62.

Leuz, C., and R. Verrecchia. 2000. The economic consequences of increased disclosure. Journal of Accounting Research 38 (Supplement):91-124.

Levenstein, M. 1997. Price wars and the sustainability of collusion: A study of the pre-world war I bromine industry. Journal of Industrial Economics 45 (2):117-137.

Levenstein, M., and V. Suslow. 2006. What determines cartel success? Journal of Economic Literature 44 (1):43-95.

- 2011. Breaking up is hard to do: Determinants of cartel duration. Journal of Law and Economics 54 (2):455-492.

Lipczynski, J., J. Wilson, and J. Goddard. 2005. Industrial organization. 2nd ed. New York: Prentice Hall.

Lisowsky, P., M. Minnis, and A. Sutherland. 2017. Economic Growth and Financial Statement Verification. Journal of Accounting Research 55 (4):745-794.

Maddala, G. S. 1983. Limited-dependent and qualitative New York: Cambridge University Press.

Minnis, M. 2011. The Value of Financial Statement Verification in Debt Financing: Evidence from Private U.S. Firms. Journal of Accounting Research 49 (2):457-506.

Minnis, M., and A. Sutherland. 2017. Financial Statements as Monitoring Mechanisms: Evidence from Small Commercial Loans. Journal of Accounting Research 55 (1):197233.

Müller, M. A., E. J. Riedl, and T. Sellhorn. 2015. Recognition versus disclosure of fair values. The Accounting Review 90 (6):2411-2447.

OECD. 2007. Glossary of statistical terms In Glossary of Statistical Terms Paris: Organisation for Economic Co-operation and Development.

- 2010. Information exchanges between competitors under competition law. Directorate for Financial and Enterprise Affairs: Competition Committee. DAF/COMP(2010)(37).

- 2013. Ex officio cartel investigations and the use of screens to detect cartels. Directorate for Financial and Enterprise Affairs: Competition Committee. DAF/COMP(2013)(27).

Orr, D., and P. W. MacAvoy. 1965. Price strategies to promote cartel stability. Economica 32 (126):186-197.

Osborne, M. J., and C. Pitchik. 1987. Cartels, profits and excess capacity. International Economic Review 28 (2):413-428.

European Parliament. 2009. Parliamentary questions: Joint answer given by EU Commissioner Kroes on behalf of the European Commission to written questions: E-0890/09, E0891/09, E-0892/09.

Pepall, L., D. J. Richards, G. Norman, and P. Debashis. 2005. Industrial organization: Contemporary theory and practice. New York: Thomson/South-Western.

Pindyck, R. S. 1977. Cartel pricing and the structure of the world bauxite market. The Bell Journal of Economics:343-360.

Porter, R. H. 1983. A Study of cartel stability: The joint executive committee, 1880-1886. The Bell Journal of Economics 14 (2):301-314. 
Posner, R. A. 1970. A statistical study of antitrust enforcement. Journal of Law and Economics 13 (2):365-419.

Roberts, K. 1985. Cartel behaviour and adverse selection. The Journal of Industrial Economics 33 (4):401-413.

Rogers, J. L., C. M. Schrand, and S. L. C. Zechman. 2014. Do managers tacitly collude to withhold industry-wide bad news? Working paper, University of Colorado at Boulder Leeds School of Business and University of Pennsylvania.

Rosenbaum, D. I. 1989. An empirical test of the effect of excess capacity in price setting, capacity-constrained supergames. International Journal of Industrial Organization 7 (2):231-241.

Sannikov, Y., and A. Skrzypacz. 2007. Impossibility of collusion under imperfect monitoring with flexible production. American Economic Review 97 (5):1794-1823.

Schwab, K., X. Sala i Martin, and W. E. Forum. 2007. The Global Competitiveness Report 20062007. ICC - International Center for Competitiveness.

Spar, D. L. 1994. The cooperative edge: The internal politics of international cartels. Ithaca: Cornell University Press.

Stigler, G. J. 1964. A theory of oligopoly. The Journal of Political Economy 72 (1):44-61.

Suslow, V. Y. 2005. Cartel contract duration: empirical evidence from inter-war international cartels. Industrial and Corporate Change 14 (5):705-744.

Telser, L. G. 1980. A theory of self-enforcing agreements. The Journal of Business 53 (1):27-44.

Tirole, J. 1988. The theory of industrial organization. Cambridge, MA: MIT Press.

Ulen, T. S. 1980. The market for regulation: The ICC from 1887 to 1920. The American Economic Review 70 (2):306-310.

Verrecchia, R. E. 2001. Essays on disclosure. Journal of Accounting and Economics 32 (1-3):97180.

Watts, R. L., and J. L. Zimmerman. 1986. Positive accounting theory. Englewood Cliffs, NJ: Prentice-Hall.

Williamson, O. E. 1973. Markets and hierarchies: Some elementary considerations. American Economic Review 63 (2):316-325.

- 1974. The economics of antitrust: Transaction cost considerations. University of Pennsylvania Law Review 122 (6):1439-1496.

Zimmerman, J. E., and J. M. Connor. 2005. Determinants of cartel duration: A cross-sectional study of modern private international cartels. Working paper, Government of the United States of America - Foreign Agricultural Service and American Antitrust Institute (AAI). 


\section{Figure 1: Kaplan Meier failure functions}

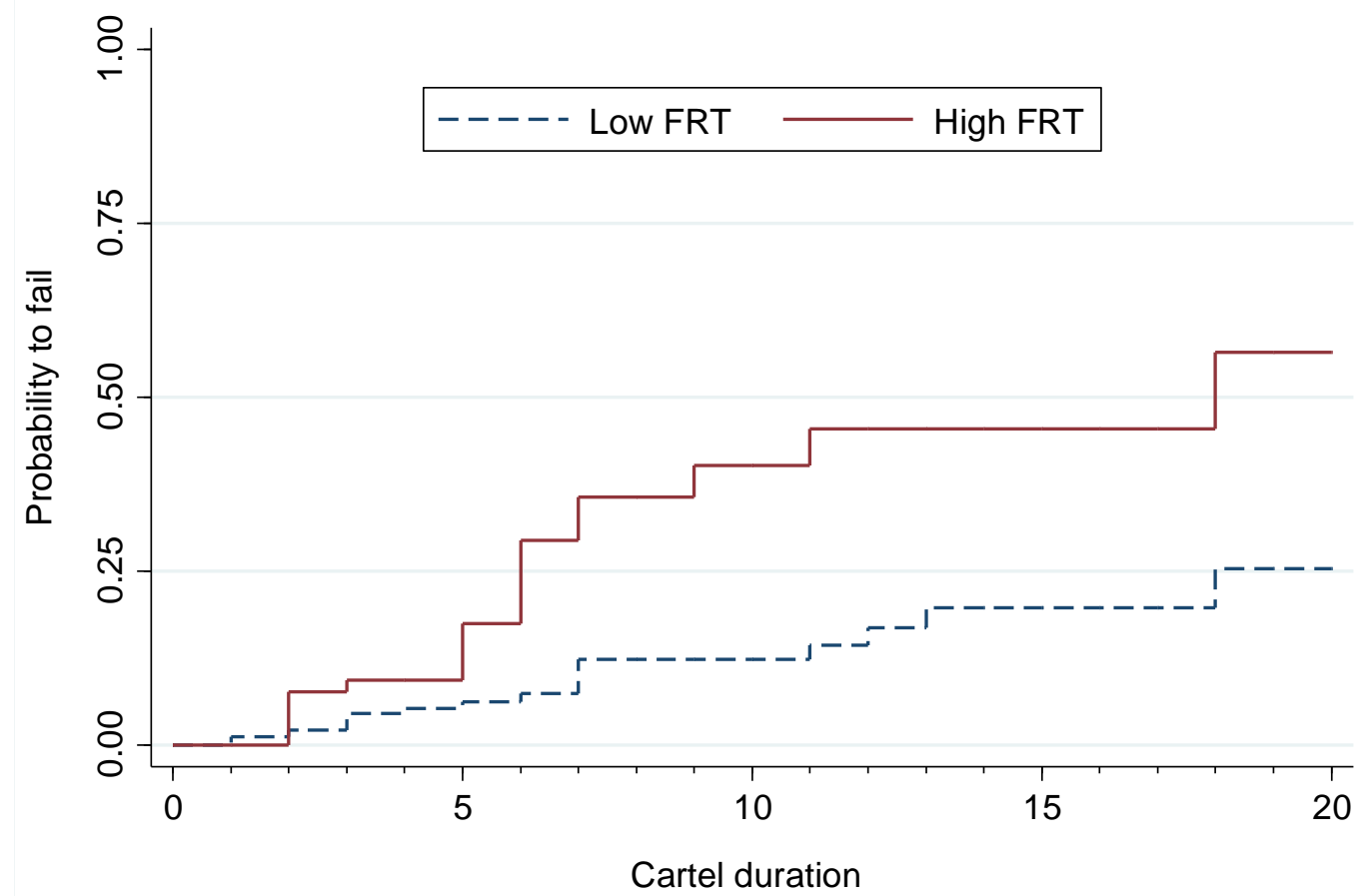

Notes: This figure shows the Kaplan-Meier failure function for firms with low $(F R T=0)$ and high $(F R T=1)$ financial reporting transparency. The functions for $F R T=1$ and $F R T=0$ are fitted from two separate Cox models using standardized values of the covariates shown in Table 3 column (1). FRT is an indicator variable that equals 1 if a firm follows IFRS or U.S. GAAP, and 0 otherwise. 
Table 1: Sample distribution across countries

\begin{tabular}{|c|c|c|c|c|c|}
\hline \multirow[t]{2}{*}{ Country } & \multirow[t]{2}{*}{$\begin{array}{l}\text { Number of } \\
\text { firm-years }\end{array}$} & \multirow[t]{2}{*}{$\%$} & \multirow[t]{2}{*}{ Cum. } & \multicolumn{2}{|c|}{ FRT } \\
\hline & & & & 0 & 1 \\
\hline AUSTRALIA & 5 & 0.47 & 0.47 & 5 & 0 \\
\hline AUSTRIA & 11 & 1.03 & 1.49 & 7 & 4 \\
\hline BELGIUM & 24 & 2.24 & 3.73 & 24 & 0 \\
\hline CZECH REPUBLIC & 2 & 0.19 & 3.92 & 2 & 0 \\
\hline DENMARK & 17 & 1.59 & 5.50 & 17 & 0 \\
\hline FINLAND & 36 & 3.36 & 8.86 & 28 & 8 \\
\hline FRANCE & 174 & 16.23 & 25.09 & 101 & 73 \\
\hline GERMANY & 146 & 13.62 & 38.71 & 104 & 42 \\
\hline GREECE & 3 & 0.28 & 38.99 & 3 & 0 \\
\hline HONG KONG & 5 & 0.47 & 39.46 & 5 & 0 \\
\hline HUNGARY & 10 & 0.93 & 40.39 & 0 & 10 \\
\hline ITALY & 36 & 3.36 & 43.75 & 10 & 26 \\
\hline JAPAN & 199 & 18.56 & 62.31 & 140 & 59 \\
\hline KOREA (SOUTH) & 3 & 0.28 & 62.59 & 3 & 0 \\
\hline LUXEMBOURG & 2 & 0.19 & 62.78 & 0 & 2 \\
\hline NETHERLANDS & 75 & 7.00 & 69.78 & 72 & 3 \\
\hline NORWAY & 3 & 0.28 & 70.06 & 3 & 0 \\
\hline SINGAPORE & 1 & 0.09 & 70.15 & 1 & 0 \\
\hline SOUTH AFRICA & 9 & 0.84 & 70.99 & 5 & 4 \\
\hline SPAIN & 44 & 4.10 & 75.09 & 44 & 0 \\
\hline SWEDEN & 25 & 2.33 & 77.43 & 20 & 5 \\
\hline SWITZERLAND & 18 & 1.68 & 79.10 & 2 & 16 \\
\hline TAIWAN & 6 & 0.56 & 79.66 & 6 & 0 \\
\hline UNITED KINGDOM & 80 & 7.46 & 87.13 & 78 & 2 \\
\hline UNITED STATES & 138 & 12.87 & 100.00 & 0 & 138 \\
\hline Total & 1,072 & 100.00 & & 680 & 392 \\
\hline
\end{tabular}


Table 2: Descriptive statistics

\begin{tabular}{|c|c|c|c|c|c|c|}
\hline & MEAN & SD & P25 & P50 & P75 & $\mathrm{N}$ \\
\hline DUR & 10.68 & 5.65 & 6.00 & 10.00 & 14.00 & 1,072 \\
\hline FRT & 0.37 & 0.48 & 0.00 & 0.00 & 1.00 & 1,072 \\
\hline LENIENCY & 0.50 & 0.50 & 0.00 & 0.00 & 1.00 & 1,072 \\
\hline FINE & 1.28 & 2.65 & 0.05 & 0.28 & 1.06 & 1,072 \\
\hline REPEAT & 0.49 & 0.50 & 0.00 & 0.00 & 1.00 & 1,072 \\
\hline \#MEMBER & 18.11 & 13.31 & 11.00 & 13.00 & 21.00 & 1,072 \\
\hline SIZE & 15.78 & 1.54 & 14.78 & 15.83 & 17.01 & 1,072 \\
\hline GDP_GROWTH & 2.45 & 1.83 & 1.26 & 2.39 & 3.72 & 1,072 \\
\hline$\triangle I N D \_S A L E S$ & 0.22 & 1.90 & -0.01 & 0.06 & 0.17 & 1,070 \\
\hline$\triangle F O R E I G N \_S A L E S \%$ & 1.55 & 10.10 & -0.54 & 0.38 & 2.56 & 1,050 \\
\hline$L O C A L \_E N F$ & 0.78 & 1.43 & 0.00 & 0.00 & 1.00 & 1,072 \\
\hline GOOD_CG & 0.46 & 0.50 & 0.00 & 0.00 & 1.00 & 1,058 \\
\hline CHEAT: Trade association & 0.78 & 0.42 & 1.00 & 1.00 & 1.00 & 1,072 \\
\hline CHEAT: Excess capacity & 0.09 & 1.95 & -0.70 & -0.00 & 0.58 & 838 \\
\hline CHEAT: Cost heterogeneity & 3.81 & 2.47 & 1.98 & 3.45 & 4.88 & 915 \\
\hline
\end{tabular}

Notes: DUR measures cartel duration in years. FRT is an indicator variable that equals 1 if a firm follows IFRS or U.S. GAAP, and 0 otherwise. LENIENCY is an indicator variable that equals 1 if the respective cartel member made use of the leniency program, and 0 otherwise. FINE is the fine imposed by the EC as percentage of total assets. REPEAT is an indicator variable that equals 1 if a cartel firm is a repeat offender, and 0 otherwise. \#MEMBER is the total number of cartel members (listed and private firms). SIZE is the natural logarithm of total assets in US\$. GDP_GROWTH is the percentage change in GDP in each cartel member's country of incorporation over a given year. $\triangle I N D \_S A L E S$ is the yearly percentage change in the sum of sales of all industry members in the same four-digit SIC code industry. $\triangle F O R E I G N \_S A L E S \%$ is the change in the ratio of foreign sales to total sales. $L O C A L \_E N F$ is the yearly number of cartels convicted by local antitrust authorities, based on Connor (2014). GOOD_CG is an indicator variable that equals 1 if the cartel firm's country of origin has a high value for the anti-director-rights index, and 0 otherwise. Trade association is an indicator variable that equals 1 if the cartel does not use a trade association and 0 otherwise. Excess capacity is the average change of inventory (scaled by total assets, and expressed in percent) of cartel members less the average change of inventory (scaled by total assets, and expressed in percent) of firms outside of the cartel matched by industry, country, and year. We multiply the variable by -1 , so that higher values of the variable (lower excess capacity) increase cheating rates. Cost heterogeneity is the standard deviation of EBIT over total assets for each cartel and year. 
Table 3: Reporting transparency and cartel membership duration

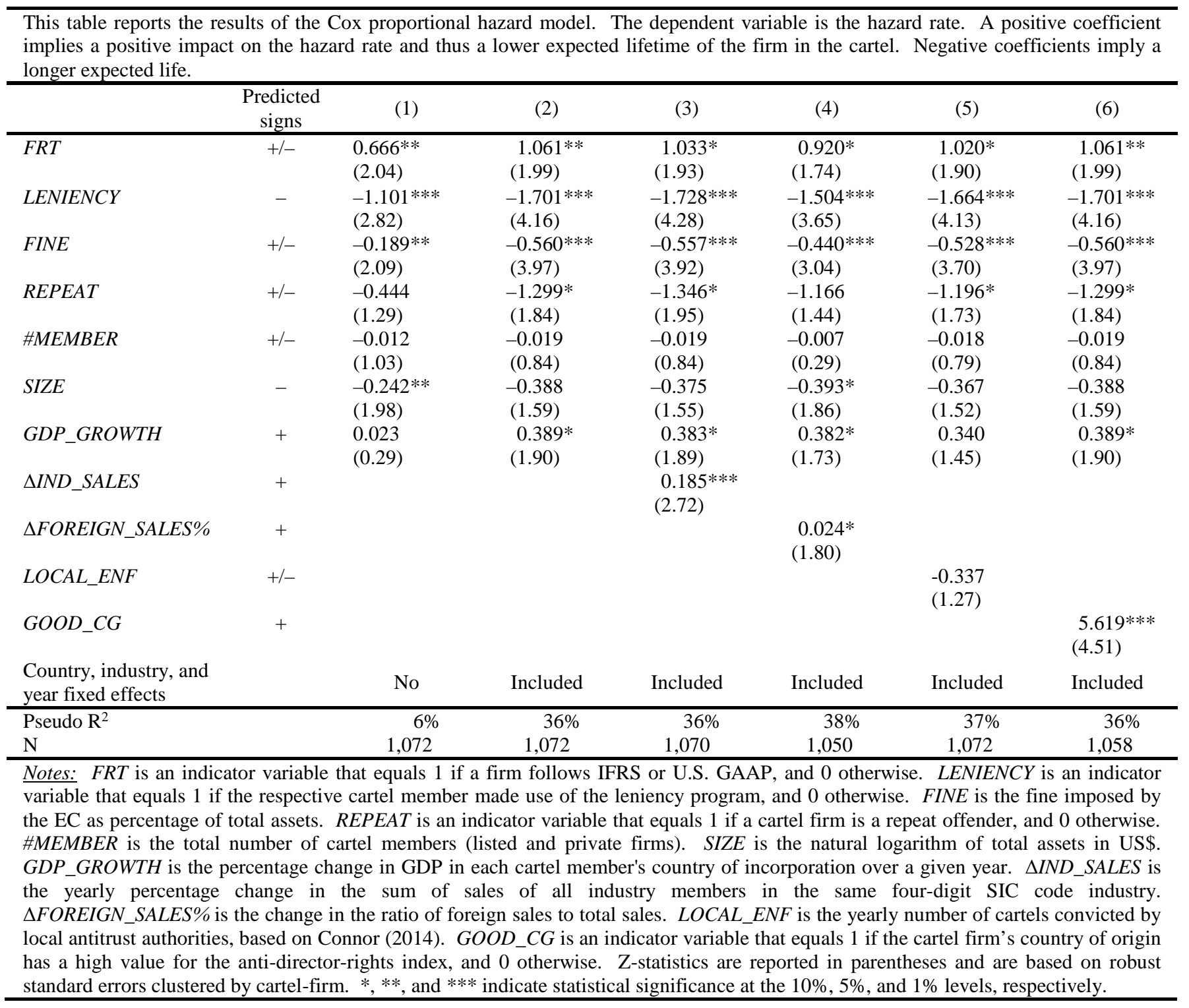


Table 4: Replicating analysis at the cartel level

\section{Panel A: Reporting transparency and cartel duration: cartel-year level of analysis}

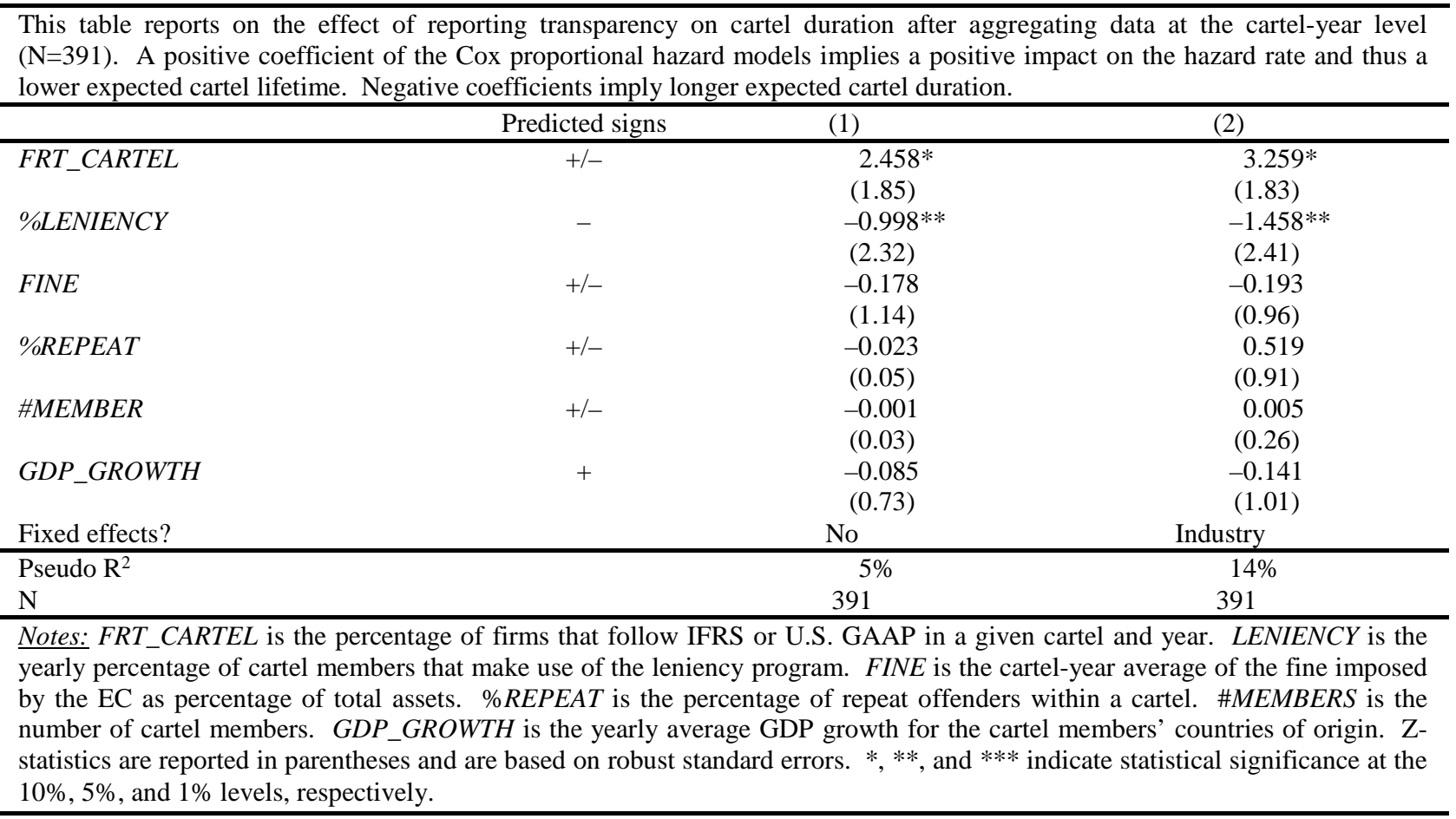

\section{Panel B: Reporting transparency and cartel duration: cartel level of analysis}

\begin{tabular}{|c|c|c|c|}
\hline & Predicted signs & (1) & (2) \\
\hline GAAP_DIFF & $+/-$ & $\begin{array}{l}0.073^{* *} \\
(2.30)\end{array}$ & $\begin{array}{l}0.084 * * \\
(2.40)\end{array}$ \\
\hline$\% L E N I E N C Y$ & - & $\begin{array}{l}-0.445 \\
(1.49)\end{array}$ & $\begin{array}{c}-0.472 \\
(1.45)\end{array}$ \\
\hline FINE & $+/-$ & $\begin{array}{l}-0.000^{* * *} \\
(2.65)\end{array}$ & $\begin{array}{l}-0.000 * * \\
(2.33)\end{array}$ \\
\hline$\% R E P E A T$ & $+/-$ & $\begin{array}{l}-1.631^{* * *} \\
(2.63)\end{array}$ & $\begin{array}{l}-1.640 * * \\
(2.05)\end{array}$ \\
\hline \#MEMBER & $+/-$ & $\begin{array}{l}-0.035^{* * * *} \\
(3.89)\end{array}$ & $\begin{array}{l}-0.033^{* * *} \\
(3.35)\end{array}$ \\
\hline Fixed effects? & & No & Industry \\
\hline $\begin{array}{l}\text { Pseudo } \mathrm{R}^{2} \\
\mathrm{~N}\end{array}$ & & $\begin{array}{l}4 \% \\
98\end{array}$ & $\begin{array}{c}4 \% \\
98\end{array}$ \\
\hline $\begin{array}{l}\text { Notes: } G A A P \\
\text { (based on Bae } \\
\text { the cartel avera } \\
\text { number of car } \\
\text { indicate statisti }\end{array}$ & $\begin{array}{l}\text { GAAP and U } \\
\text { e percentage of } \\
\text { ported in parent } \\
\text { and } 1 \% \text { levels, }\end{array}$ & $\begin{array}{l}\text { eraged across } \\
\text { rs that made u } \\
\text { of repeat offe } \\
\text { based on rob }\end{array}$ & $\begin{array}{l}\text { rs and multiplie } \\
\text { ency program. } \\
\text { artel. \#MEMBE } \\
\text { errors. *, **, a }\end{array}$ \\
\hline
\end{tabular}




\section{Table 5: Reporting transparency, cheating and cartel duration}

\begin{tabular}{|c|c|c|c|c|c|}
\hline \multicolumn{6}{|c|}{$\begin{array}{l}\text { This table examines whether the effect of reporting transparency on cartel duration is conditional on } \\
\text { the likelihood that a cartel member deviates from the cartel agreement. The table reports the results o } \\
\text { model, where the dependent variable is the hazard rate. A positive coefficient implies a positive impa } \\
\text { a lower expected lifetime of the cartel. Negative coefficients imply a longer expected life. } \\
\text { Cheating proxy CHEAT = }\end{array}$} \\
\hline \multirow{2}{*}{\multicolumn{2}{|c|}{$\begin{array}{l}\text { Predicted } \\
\text { signs }\end{array}$}} & $\begin{array}{c}\text { Trade } \\
\text { association }\end{array}$ & \multirow{2}{*}{$\begin{array}{l}\text { Excess } \\
\text { capacity } \\
(2)\end{array}$} & \multirow{2}{*}{$\begin{array}{c}\begin{array}{c}\text { Cost } \\
\text { heterogeneity }\end{array} \\
\text { (3) }\end{array}$} & \multirow{2}{*}{$\begin{array}{l}\text { Trade association } \\
+ \text { Excess capacity } \\
+ \text { Cost heterogeneity } \\
(4)\end{array}$} \\
\hline & & (1) & & & \\
\hline$\overline{F R T}$ & $+/-$ & $\begin{array}{l}-0.313 \\
(0.35)\end{array}$ & $\begin{array}{l}1.553^{* *} \\
(2.53)\end{array}$ & $\begin{array}{c}-0.601 \\
(0.50)\end{array}$ & $\begin{array}{r}2.782 \\
(0.63)\end{array}$ \\
\hline$F R T \times C H E A T$ & + & $\begin{array}{l}1.980 * \\
(1.91)\end{array}$ & $\begin{array}{l}0.343 * * \\
(2.03)\end{array}$ & $\begin{array}{l}0.497^{* *} \\
(2.06)\end{array}$ & $\begin{array}{l}8.967^{* * *} \\
(2.07)\end{array}$ \\
\hline CHEAT & $+/-$ & $\begin{array}{l}-0.967 \\
(1.33)\end{array}$ & $\begin{array}{l}-0.159 \\
(0.97)\end{array}$ & $\begin{array}{l}-0.411^{*} \\
(1.87)\end{array}$ & $\begin{array}{l}-3.070^{* *} \\
(2.45)\end{array}$ \\
\hline LENIENCY & - & $\begin{array}{l}-1.628 * * * \\
(4.29)\end{array}$ & $\begin{array}{c}-1.476^{* * * *} \\
(3.24)\end{array}$ & $\begin{array}{l}-1.434 * * * \\
(2.58)\end{array}$ & $\begin{array}{c}0.741 \\
(0.87)\end{array}$ \\
\hline FINE & $+/-$ & $\begin{array}{l}-0.669 * * * \\
(3.68)\end{array}$ & $\begin{array}{l}-0.378^{* *} \\
(2.53)\end{array}$ & $\begin{array}{l}-0.518^{* * *} \\
(2.61)\end{array}$ & $\begin{array}{r}-0.135 \\
(0.71)\end{array}$ \\
\hline REPEAT & $+/-$ & $\begin{array}{r}-1.027 \\
(1.54)\end{array}$ & $\begin{array}{c}-0.783 \\
(1.26)\end{array}$ & $\begin{array}{r}-1.877 \\
(1.52)\end{array}$ & $\begin{array}{c}0.819 \\
(0.88)\end{array}$ \\
\hline \#MEMBER & $+1-$ & $\begin{array}{l}-0.026 \\
(1.05)\end{array}$ & $\begin{array}{l}-0.022 \\
(1.35)\end{array}$ & $\begin{array}{l}-0.034 \\
(1.52)\end{array}$ & $\begin{array}{l}-0.005 \\
(0.25)\end{array}$ \\
\hline SIZE & - & $\begin{array}{l}-0.520 * * \\
(2.02)\end{array}$ & $\begin{array}{l}-0.406 \\
(1.49)\end{array}$ & $\begin{array}{c}-0.441 \\
(1.00)\end{array}$ & $\begin{array}{r}0.289 \\
(0.98)\end{array}$ \\
\hline GDP_GROWTH & + & $\begin{array}{l}0.341^{* *} \\
(2.05)\end{array}$ & $\begin{array}{l}0.401^{*} \\
(1.65)\end{array}$ & $\begin{array}{l}0.460 * * \\
(2.05)\end{array}$ & $\begin{array}{c}0.741 \\
(0.87)\end{array}$ \\
\hline $\begin{array}{l}\text { Country, industry, and } \\
\text { year fixed effects? }\end{array}$ & & All included & All included & All included & Industry \\
\hline Unit of analysis? & & Firm-year & Firm-year & Firm-year & Cartel-year \\
\hline $\begin{array}{l}\text { Pseudo } \mathrm{R}^{2} \\
\mathrm{~N}\end{array}$ & & $\begin{array}{c}37 \% \\
1,072\end{array}$ & & $\begin{array}{c}41 \% \\
915\end{array}$ & $\begin{array}{c}27 \% \\
207\end{array}$ \\
\hline $\begin{array}{l}\text { Notes: Columns (1) - ( } \\
\text { if a firm follows IFRS } \\
\text { does not use a trade as } \\
\text { inventory (scaled by to } \\
\text { percent) of firms outsid } \\
\text { of the variable (lower } \\
\text { heterogeneity, defined } \\
\text { defined as reported in T } \\
\text { as the percentage of firl } \\
\text { CHEAT in column (4) } \\
\text { heterogeneity values ar } \\
\text { yearly percentage of car } \\
\text { the EC as a percentage } \\
\text { of cartel members. SI2 } \\
\text { growth for the cartel m } \\
* \text {, **, and } * * * \text { indicate }\end{array}$ & $\begin{array}{l}\text { firm-year c } \\
\text { GAAP, a } \\
\text { on, and } 0 \text { c } \\
\text { ts) of cart } \\
\text { e cartel ma } \\
\text { capacity, } \\
\text { standard de } \\
\text { Column } \\
\text { follow IF } \\
\text { indicator v } \\
\text { e second o } \\
\text { mbers that } \\
\text { l assets. \% } \\
\text { he average } \\
\text { cal countries } \\
\text { cal signific }\end{array}$ & $\begin{array}{l}\text { d specify variabl } \\
\text { therwise. CHEA } \\
\text { ise. CHEAT in c } \\
\text { abers less the ave } \\
\text { oy industry, coun } \\
\text { spressed in perce } \\
\text { n of EBIT over t } \\
\text { s cartel-year data } \\
\text { U.S. GAAP in a } \\
\text { that equals } 1 \text { if } \\
\text { tertile of their re } \\
\text { use of the lenienc } \\
\text { AT is the percent } \\
\text { f total assets in } ~ \\
\text { gin. Z-statistics } \\
\text { the } 10 \%, 5 \% \text {, an }\end{array}$ & $\begin{array}{l}\text { the following } \\
\text { column (1) is } \\
\text { mn (2) is exces } \\
\text { change of inv } \\
\text { and year. We } \mathrm{n} \\
\text { increase cheati } \\
\text { assets for each } \\
\text { defines all var } \\
\text { n cartel and ye } \\
\text { cartel has no t } \\
\text { tive sample dis } \\
\text { ogram. FINE i } \\
\text { of repeat offenc } \\
\text { in a given year } \\
\text { eported in pare } \\
\text { o levels, respec }\end{array}$ & $\begin{array}{l}\text { FRT is an indic } \\
\text { indicator variable } \\
\text { pacity, calculated } \\
\text { ry (scaled by tot } \\
\text { ply the variable b } \\
\text { ates. CHEAT in } \\
\text { tel and year. All } \\
\text { es at the cartel-ye } \\
\text { ame as FRT_CA } \\
\text { association, and } \\
\text { utions, and } 0 \text { oth } \\
\text { e cartel-year aver } \\
\text { within a cartel. } \\
\text { sDP_GROWTH i } \\
\text { ses and are based } \\
\text { ly. }\end{array}$ & $\begin{array}{l}\text { r variable that equals } 1 \\
\text { at equals } 1 \text { if the cartel } \\
\text { the average change of } \\
\text { ssets, and expressed in } \\
1 \text {, so that higher values } \\
\text { lumn (3) is cartel cost } \\
\text { er control variables are } \\
\text { level. FRT is redefined } \\
E L \text { in Table } 4 \text { panel A). } \\
\text { cess capacity and cost } \\
\text { ise. LENIENCY is the } \\
\text { of the fine imposed by } \\
E M B E R S \text { is the number } \\
\text { te yearly average GDP } \\
\text { robust standard errors. }\end{array}$ \\
\hline
\end{tabular}


Table 6: Financial reporting transparency, segment reporting, and cartel duration

\section{Panel A: Financial reporting transparency and segment reporting}

This table compares the average number of reported segments between firms reporting under transparent accounting standards (IFRS or U.S. GAAP) and those reporting under local GAAP.

(1) Full sample

(2) Full sample after excluding

(3) Switchers from local GAAP to IFRS

U.S. GAAP firms

\begin{tabular}{|c|c|c|c|c|c|c|}
\hline & $\mathrm{N}$ & No. of Segments & $\mathrm{N}$ & No. of Segments & $\mathrm{N}$ & No. of Segments \\
\hline$F R T=0$ & 680 & 3.19 & 680 & 3.19 & 85 & 2.73 \\
\hline$F R T=1$ & 392 & 4.42 & 254 & 4.80 & 81 & 4.06 \\
\hline $\begin{array}{l}\text { Diff. } \\
\text { p-value }\end{array}$ & & $\begin{array}{l}-1.23 \\
<0.01\end{array}$ & & $\begin{array}{l}-1.61 \\
<0.01\end{array}$ & & $\begin{array}{l}-1.33 \\
<0.01\end{array}$ \\
\hline
\end{tabular}

Notes: Column (1) compares the mean number of segments reported by quoted cartel members that follow IFRS or U.S. GAAP

$\overline{(F R T}=1)$ against the number of segments reported by firms following local GAAP $(F R T=0)$. Column $(2)$ compares the mean number of segments reported by quoted cartel members that follow IFRS $(F R T=1)$ against the number of segments reported by firms following local GAAP $(F R T=0)$. Column (3) compares the mean number of reported segments before $(F R T=0)$ and after IFRS adoption $(F R T=1)$ for quoted cartel members that adopted IFRS during the sample period. The bottom row reports the pvalue of the t-test, which compares means across the samples.

\section{Panel B: Cox proportional hazard model: firm level of analysis}

\begin{tabular}{|c|c|c|c|}
\hline \multicolumn{4}{|c|}{$\begin{array}{l}\text { This table tests hypothesis } 2 \text { and examines whether transparent segment reporting affects cartel duration. I } \\
\text { proportional hazard models using cartel-firm-level data in columns (1) and (2). The dependent variable is } \mathrm{t} \\
\text { coefficient implies a positive impact on the hazard rate and thus a lower expected lifetime of the cartel. } \mathrm{N} \\
\text { longer expected cartel duration. }\end{array}$} \\
\hline \multirow{2}{*}{\multicolumn{2}{|c|}{$\begin{array}{c}\text { Predicted } \\
\text { signs } \\
\end{array}$}} & \#Segments & \multirow{2}{*}{$\frac{\text { \#Reclassifications }}{(2)}$} \\
\hline & & (1) & \\
\hline SEGTRANS & $+/-$ & $\begin{array}{l}0.298^{* *} \\
(2.32)\end{array}$ & $\begin{array}{l}2.378^{* * *} \\
(2.74)\end{array}$ \\
\hline LENIENCY & - & $\begin{array}{l}-1.824 * * * \\
(4.04)\end{array}$ & $\begin{array}{l}-1.575^{* * *} \\
(3.06)\end{array}$ \\
\hline FINE & $+/-$ & $\begin{array}{l}-0.562 * * * \\
(4.09)\end{array}$ & $\begin{array}{l}-0.608 * * * \\
(2.86)\end{array}$ \\
\hline REPEAT & $+/-$ & $\begin{array}{l}-1.459 * \\
(1.93)\end{array}$ & $\begin{array}{r}-1.191 \\
(1.29)\end{array}$ \\
\hline \#MEMBER & $+/-$ & $\begin{array}{c}-0.026 \\
(1.20)\end{array}$ & $\begin{array}{c}-0.028 \\
(0.73)\end{array}$ \\
\hline SIZE & - & $\begin{array}{l}-0.438^{*} \\
(1.83)\end{array}$ & $\begin{array}{r}-0.362 \\
(1.48)\end{array}$ \\
\hline GDP_GROWTH & + & $\begin{array}{l}0.381^{*} \\
(1.87)\end{array}$ & $\begin{array}{r}0.249 \\
(1.51)\end{array}$ \\
\hline \multicolumn{2}{|l|}{ Country, industry, and year FE? } & Included & Included \\
\hline \multicolumn{2}{|l|}{$\begin{array}{l}\text { Pseudo } \mathrm{R}^{2} \\
\mathrm{~N}\end{array}$} & $\begin{array}{c}36 \% \\
1,072\end{array}$ & $\begin{array}{l}37 \% \\
765\end{array}$ \\
\hline \multicolumn{4}{|c|}{$\begin{array}{l}\text { Notes: In column (1) SEGTRANS is the average number of segments reported by cartel firms in a given year. In column (2) } \\
\text { SEGTRANS is the average number of segment reclassifications in the cartel multiplied by }-1 \text {, so that higher (lower) values of this } \\
\text { variable indicate greater (lower) reporting transparency. LENIENCY is an indicator variable that equals } 1 \text { if the respective cartel } \\
\text { member made use of the leniency program, and } 0 \text { otherwise. FINE is the fine imposed by the EC as percentage of total assets. } \\
\text { REPEAT is an indicator variable that equals } 1 \text { if a cartel firm is a repeat offender, and } 0 \text { otherwise. \#MEMBER is the total number of } \\
\text { cartel members (listed and private firms). SIZE is the natural logarithm of total assets in US\$. GDP_GROWTH is the percentage } \\
\text { change in GDP in each cartel member's country of incorporation over a given year. Z-statistics are reported in parentheses and are } \\
\text { based on robust standard errors clustered by cartel-firm. *, **, and *** indicate statistical significance at the } 10 \%, 5 \% \text {, and } 1 \% \\
\text { levels, respectively. }\end{array}$} \\
\hline
\end{tabular}




\section{Panel C: Segment reporting and cartel duration: cartel level of analysis}

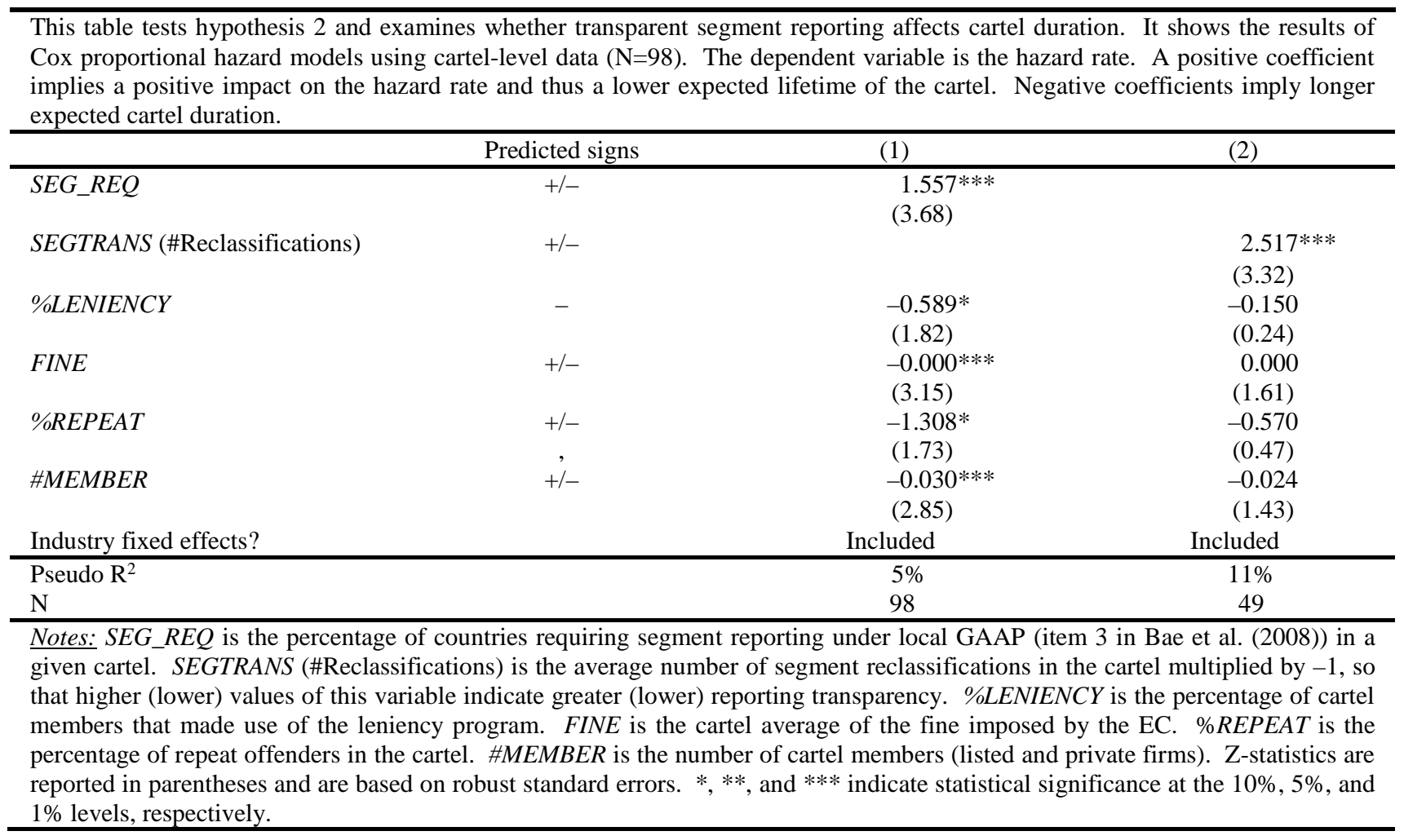




\section{Table 7: Controlling for the choice to adopt a transparent accounting framework}

\begin{tabular}{|c|c|c|c|c|}
\hline & & Full sample & $\begin{array}{l}\text { Excluding U.S. } \\
\text { firms }\end{array}$ & $\begin{array}{l}\text { U.S. GAAP vs. } \\
\text { local GAAP }\end{array}$ \\
\hline & Predicted signs & $(1)$ & $(2)$ & (3) \\
\hline$F R T \_P R O P$ & $+/-$ & $\begin{array}{l}1.797^{* *} \\
(2.23)\end{array}$ & $\begin{array}{l}1.915^{*} \\
(1.81)\end{array}$ & \\
\hline USGAAP & $+1-$ & & & $\begin{array}{c}21.589 * * * \\
(6.83)\end{array}$ \\
\hline LENIENCY & - & $\begin{array}{c}-1.797 * * * \\
(4.49)\end{array}$ & $\begin{array}{l}-2.581^{* * *} \\
(4.39)\end{array}$ & $\begin{array}{l}-2.623^{* *} \\
(2.28)\end{array}$ \\
\hline FINE & $+/-$ & $\begin{array}{c}-0.597 * * * \\
(4.33)\end{array}$ & $\begin{array}{l}-0.756^{* * *} \\
(5.26)\end{array}$ & $\begin{array}{c}-0.189 \\
(0.87)\end{array}$ \\
\hline REPEAT & $+/-$ & $\begin{array}{l}-1.382 * * \\
(2.10)\end{array}$ & $\begin{array}{l}-1.188 \\
(1.47)\end{array}$ & $\begin{array}{l}-0.494 \\
(0.46)\end{array}$ \\
\hline \#MEMBER & $+/-$ & $\begin{array}{c}-0.015 \\
(0.63)\end{array}$ & $\begin{array}{c}-0.026 \\
(1.54)\end{array}$ & $\begin{array}{c}-0.028 \\
(1.20)\end{array}$ \\
\hline SIZE & - & $\begin{array}{l}-0.437 * \\
(1.96)\end{array}$ & $\begin{array}{l}-0.587 * \\
(1.69)\end{array}$ & $\begin{array}{r}0.047 \\
(0.07)\end{array}$ \\
\hline GDP_GROWTH & + & $\begin{array}{l}0.434^{* *} \\
(2.11)\end{array}$ & $\begin{array}{c}0.346 \\
(1.44)\end{array}$ & $\begin{array}{l}1.013 \\
(1.58)\end{array}$ \\
\hline $\begin{array}{l}\text { Country, industry, } \\
\text { and year fixed effects }\end{array}$ & & Included & Included & Included \\
\hline $\begin{array}{l}\text { Pseudo } \mathrm{R}^{2} \\
\mathrm{~N}\end{array}$ & & $\begin{array}{r}36 \% \\
1,072 \\
\end{array}$ & $\begin{array}{l}41 \% \\
934 \\
\end{array}$ & $\begin{array}{l}51 \% \\
606 \\
\end{array}$ \\
\hline \multicolumn{5}{|c|}{$\begin{array}{l}\text { Notes: In column (1), FRT_PROP equals } 0 \text { for firms that report under local GAAP and have no choice to report } \\
\text { under IFRS, } 1 \text { for firms that face a mandatory requirement to report under U.S. GAAP, and a predicted (out-of- } \\
\text { sample) probability of adopting IFRS or local GAAP for firms that had a choice between IFRS and local GAAP. } \\
\text { Column (2) uses the same model as column (1), but excludes U.S. firms. Column (3) uses a sub-sample of firms that } \\
\text { were required to use U.S. GAAP or local GAAP. LENIENCY is an indicator variable that equals } 1 \text { if the respective } \\
\text { cartel member made use of the leniency program, and } 0 \text { otherwise. FINE is the fine imposed by the EC as } \\
\text { percentage of total assets. REPEAT is an indicator variable that equals } 1 \text { if a cartel firm is a repeat offender, and } 0 \\
\text { otherwise. \#MEMBER is the total number of cartel members (listed and private firms). SIZE is the natural logarithm } \\
\text { of total assets in US\$. GDP_GROWTH is the percentage change in GDP in each cartel member's country of } \\
\text { incorporation over a given year. Z-statistics are reported in parentheses and are based on robust standard errors } \\
\text { clustered by cartel-firm. } *, * * \text {, and } * * * \text { indicate statistical significance at the } 10 \%, 5 \% \text {, and } 1 \% \text { levels, respectively. }\end{array}$} \\
\hline
\end{tabular}


Table 8: Controlling for selection bias due to sampling of indicted cartels

\section{Panel A: First-stage probit estimation}

This table reports the results of the first-stage probit estimation using a sample of cartel firms $(\mathrm{N}=1,072)$ and two different control samples of firms: (1) non-cartel firms from cartel countries, industries, and of similar size (column 1); and (2) non-cartel firms from countries with lax competition enforcement, but from cartel industries, and of similar size (column 2). The dependent variable in (1) and (2) is DETECT, which equals 1 for cartel firms indicted by the EC for forming an illegal cartel, and 0 for the control firms.

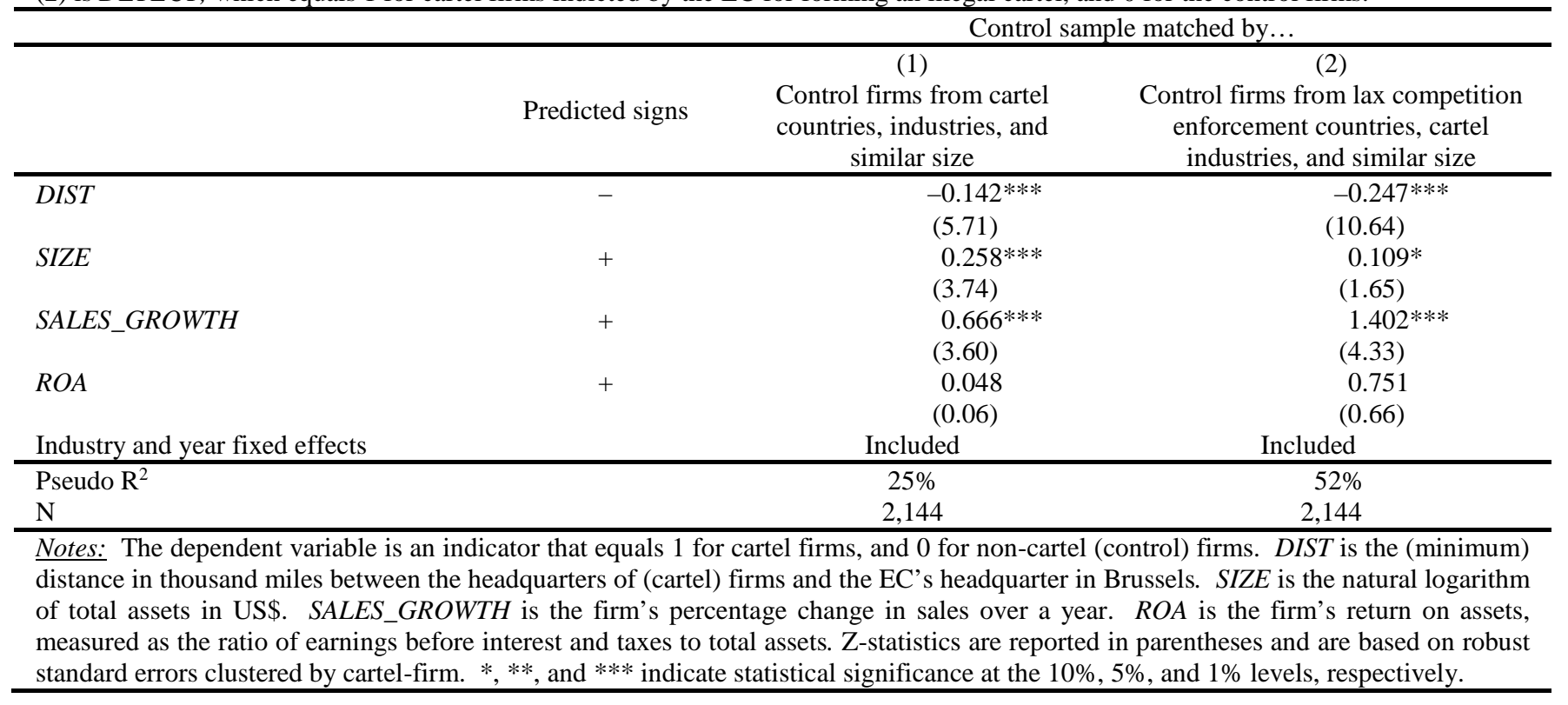

\section{Panel B: Second-stage proportional hazard model}

This table shows the results of the second-stage proportional hazard model that includes the inverse Mills ratios from Panel A. In the Cox proportional hazard model estimations, the dependent variable is the hazard rate, and a positive coefficient implies a positive impact on the hazard rate and thus a lower expected lifetime of the firm in the cartel.

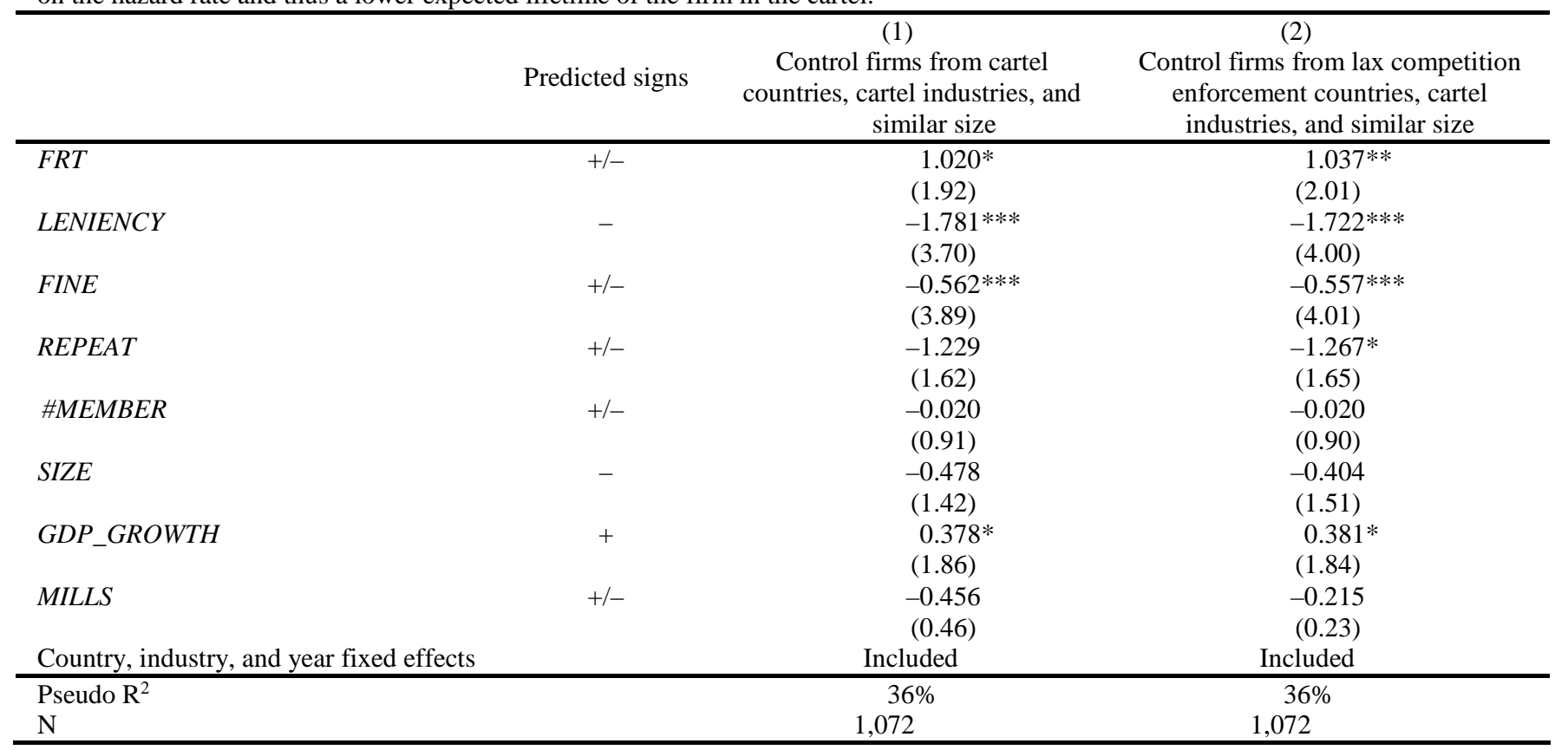


Notes: In column (1), cartel firms are matched to non-cartel (control) firms in the same country, the four-digit SIC code, year, and of

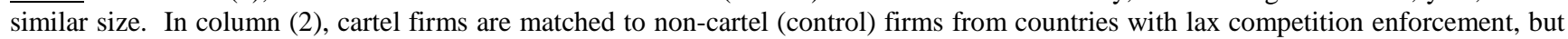
from the same four-digit SIC code and year, and are of similar size. FRT is an indicator variable that equals 1 if a firm follows IFRS or U.S. GAAP, and 0 otherwise. $L E N I E N C Y$ is an indicator variable that equals 1 if the respective cartel member made use of the leniency program, and 0 otherwise. FINE is the fine imposed by the EC as percentage of total assets. REPEAT is an indicator variable that equals 1 if a cartel firm is a repeat offender, and 0 otherwise. \#MEMBER is the total number of cartel members (listed and private firms). SIZE is the natural logarithm of total assets in US\$. GDP_GROWTH is the percentage change in GDP in each cartel member's country of incorporation over a given year. MILLS is the inverse Mills ratio calculated using the coefficient estimates from the first-stage regressions in Panel A column (1) and column (2), respectively. Z-statistics are reported in parentheses and are based on robust standard errors clustered by cartel-firm. *,**, and *** indicate statistical significance at the $10 \%, 5 \%$, and $1 \%$ levels, respectively. 